Check for updates

Cite this: RSC Adv., 2020, 10, 9274

Received 20th December 2019 Accepted 14th February 2020

DOI: 10.1039/c9ra10765g

rsc.li/rsc-advances

\section{Nystatin-mediated bismuth oxide nano-drug synthesis using gamma rays for increasing the antimicrobial and antibiofilm activities against some pathogenic bacteria and Candida species}

\author{
Ahmed I. El-Batal, (D) a Hanady G. Nada, (DD *a Reham R. El-Behery, ${ }^{a}$ \\ Mohamed Gobara (D) ${ }^{b}$ and Gharieb S. El-Sayyad (D) *a
}

\begin{abstract}
The novelty of the present research is the synthesis of bismuth oxide nanoparticles $\left(\mathrm{Bi}_{2} \mathrm{O}_{3} \mathrm{NPs}\right)$ loaded with the antifungal nystatin drug via gamma rays for increased synergistic antimicrobial potential against some pathogenic bacteria and Candida species. The full characterization of the synthesized $\mathrm{Bi}_{2} \mathrm{O}_{3} \mathrm{NPs}-$ Nystatin was achieved by XRD, FT-IR, HR-TEM, and SEM/EDX mapping techniques in order to analyze the crystallinity, chemical functional groups, average particle size, morphology, and elemental structure, respectively. The antimicrobial activities of $\mathrm{Bi}_{2} \mathrm{O}_{3}$ NPs-Nystatin were examined against pathogenic bacteria and Candida species, including the zone of inhibition (ZOI), minimum inhibitory concentration (MIC), and antibiofilm activity. Additionally, the SEM/EDX method was performed to investigate the mode of action on the treated Candida cells. Our results revealed that $\mathrm{Bi}_{2} \mathrm{O}_{3}$ NPs-Nystatin possessed a wellcrystallized semi-spherical shape with an average particle size of $27.97 \mathrm{~nm}$. EDX elemental study of the synthesized $\mathrm{Bi}_{2} \mathrm{O}_{3}$ NPs-Nystatin indicated a high level of purity. Interestingly, the synthesized $\mathrm{Bi}_{2} \mathrm{O}_{3} \mathrm{NPs}-$ Nystatin displayed encouraging antibacterial behavior against almost all the tested bacteria and a synergistic antifungal potential toward the investigated Candida species. Additionally, $\mathrm{Bi}_{2} \mathrm{O}_{3} \mathrm{NPs}-$ Nystatin was found to be a promising antibiofilm agent, resulting in inhibition percentages of $94.15 \%$ and $84.85 \%$ against $C$. albicans (1) and $E$. coli, respectively. The present research provides a revolutionary nano-drug-based solution to address the increasing global resistance of pathogenic microbes at low concentrations, thus offering a new infectious disease treatment technique that is cost effective, ecofriendly, and works in an acceptable time frame.
\end{abstract}

\section{Introduction}

Like many microbes, some fungi live naturally as commensals inside human and animal bodies. However, fungal diseases happen when a pathogenic fungus invades a patient's body and affects their immune system. ${ }^{1}$ The most common fungi that possess the capability to create life-threatening infections include Candida albicans and Aspergillus fumigates. ${ }^{2}$ Candida species are classified as the fourth most common reason for clinical and systemic diseases in the USA, with aggressive death rates of up to $55 \% .^{3}$

C. albicans is categorized as an opportunistic pathogen that can also be observed as a part of the normal microflora in the digestive systems of animals and humans. ${ }^{4}$ However, a slight change in the host protection system can support the

${ }^{a}$ Drug Radiation Research Department, National Centre for Radiation Research and Technology (NCRRT), Egyptian Atomic Energy Authority (EAEA), P. O. Box 29, Nasr City, Cairo, Egypt.E-mail: Gharieb.Elsayyad@eaea.org.eg; hanady.nada@eaea.org.eg ${ }^{b}$ Chemical Engineering Department, Military Technical College (MTC), Egyptian Armed Forces, Cairo, Egypt conversion of $C$. albicans into a pathogen that is capable of producing diseases. ${ }^{5}$ They can create two major kinds of diseases in humans: surface diseases (oral or vaginal candidiasis) and life-endangering systemic diseases. ${ }^{6}$ There are some determinants willing to enhancing the virulence of Candida species such as the expanded usage of complete parenteral diet, intravenous catheters, broad-spectrum antibiotics, and cytotoxic chemotherapy. ${ }^{7}$

Tremendous progress in fungal diagnostics and antifungal medication has been made in the past 25 years; however, this has not been reflected in significant changes in antifungal production. ${ }^{8}$ The emergence of $C$. albicans has highlighted some real challenges because several species present different levels of resistance (acquired or natural), creating difficulties for the generally applied antifungal drugs to work effectively. ${ }^{9}$ The elevated number of drug-resistant fungal pathogens and the toxicity of the present antifungal composites have focused significant attention to the antimicrobial potential of biogenic nano-based composites. ${ }^{\mathbf{1 0}}$ 
It must be noted that a small number of antifungal agents have been prepared for use in yeast treatment, most of which are considered as fungistatic. One of the key challenges associated with the treatment of bacterial and fungal infections with conventional drugs is that a tremendous resistance to antimicrobial drugs can occur, which is thus driving the research for alternative therapies. ${ }^{\mathbf{1 1}}$ There are some articles in the literature $^{\mathbf{1 2 , 1 3}}$ regarding some examples of candidosis that were found to be clinically resistant to nystatin therapy, which makes the treatment of some Candida sp. by nystatin very difficult and requires nystatin to be incorporated into a nano-carrier.

Nanotechnology is an actively emerging discipline with great application potential in many fields, including pharmaceutics, chemistry, plant pathology, and biomedicine, and refers to materials with very small dimensions (at the atomic or molecular scales). In particular, in biomedical applications, a bionanotechnique is a proper method for eliminating or minimizing the attack of different pathogenic bacteria and fungi by administering a nano-drug. ${ }^{\mathbf{1 4}}$ Many synthetic methods, like thermal reduction ${ }^{15}$ and biological synthesis, ${ }^{14}$ have been used to make metal oxide NPs. ${ }^{16}$

There is an increasing need for the green synthesis of metal oxide NPs for their application in pharmaceutical and biomedical fields due to their superior chemical, physical, and catalytic properties. Due to the encouraging characteristics of the prepared metal oxide NPs, they have found possible applications in biomedicine as anticancer and antimicrobial agents. ${ }^{17}$

However, the interactions between metal oxide NPs and biological systems depend on the cell type and uptake routes or the direction of different organelles. Despite the evolution of research in nanotechnology, there remain considerable challenges to overcome, including safety, scale-up production, decreasing costs, and understanding the biological activity. ${ }^{\mathbf{1 8}}$ Nowadays, the safety concerns of using metal oxide NPs are considered one of the main future challenges for biomedical applications. ${ }^{18}$ Here, we tried to decrease the toxicity of the prepared metal oxide NPs by incorporation with a resistantnystatin drug to increase the synergistic effect and decrease the necessary applied-dose in order to reduce the nanotoxicity, which means reducing the negative influence of the metal oxide NPs on the biological organisms. ${ }^{18,19}$

$\mathrm{Bi}_{2} \mathrm{O}_{3}$ NPs have a large surface area with various electrochemical balances and they have delivered important attention due to their potential applications for zinc sensing. ${ }^{20}$ Owing to their unique properties (non-toxic behavior, biocompatibility, and high chemical stability), they have been used as antibacterial and antifungal agents. ${ }^{21}$ There are some research reports on the antibacterial and antifungal activities of $\mathrm{Bi}_{2} \mathrm{O}_{3}$ NPs, including from Hernandez et al., ${ }^{22}$ who investigated the fungicidal activity of $\mathrm{Bi}_{2} \mathrm{O}_{3}$ NPs against $C$. albicans as well as their antibiofilm capabilities, and showed that the $\mathrm{Bi}_{2} \mathrm{O}_{3}$ NPs displayed antimicrobial activity against C. albicans growth, reducing the colony size by $85 \%$, and effected a complete inhibition of biofilm formation. Also, El-Batal et al. ${ }^{23}$ synthesized green $\mathrm{Bi}_{2} \mathrm{O}_{3}$ NPs from melanin pigment using gamma rays and examined their antimicrobial activity against some standard pathogenic bacteria and Candida sp. Their results indicated that the $\mathrm{Bi}_{2} \mathrm{O}_{3}$ NPs were active against Escherichia coli (13.0 mm ZOI), Staphylococcus epidermidis (23.0 mm ZOI), and C. albicans (20.0 mm ZOI).

Herein, we synthesized the nano-drug $\mathrm{Bi}_{2} \mathrm{O}_{3}$ NPs-Nystatin by gamma rays, which serves an eco-friendly and cost-efficient method. Full characterization techniques were performed to demonstrate the various properties of the synthesized $\mathrm{Bi}_{2} \mathrm{O}_{3}$ NPs-Nystatin. The synthesized $\mathrm{Bi}_{2} \mathrm{O}_{3}$ NPs-Nystatin possessed a small size, high crystallinity, complete elemental distribution, simplicity, and acceptable purity, which in turn led to elevated antimicrobial and antibiofilm activities. The significance of our results and findings is in the possible application of a new nano-drug synthesized by a green method at low concentration (to avoid the nanotoxicity and to reduce the used nystatin dose), which increases the synergistic potential of the nystatin drug against pathogenic microbes.

\section{Materials and methods}

\section{Chemicals and reagents used}

The media components were purchased from Hi-Media and Difco. The chemicals, such as bismuth nitrate, nystatin (NS), polyvinylpyrrolidone (PVP), dimethyl sulfoxide (DMSO), isopropyl alcohol, and other reagents used in the following tests (biological procedures) were utilized at the analytical grade as purchased from Sigma-Aldrich.

\section{Radiation source}

The gamma-irradiation process was conducted at the NCRRT, Cairo, Egypt. The source of radiation was the 60Co-Gamma chamber 4000-A-India. The applied dose rate was fixed at 2.02 $\mathrm{kGy} \mathrm{h}^{-1}$. Gamma rays produce a free radical and solvated electrons after water radiolysis.

\section{Synthesis and optimization of $\mathrm{Bi}_{2} \mathrm{O}_{3}$ NPs by the nystatin drug and gamma rays}

$\mathrm{Bi}_{2} \mathrm{O}_{3}$ NPs were synthesized and incorporated the nystatin drug via applying gamma rays (as a reducing agent) in the presence of a capping polymer, like polyvinylpyrrolidone (PVP). Briefly, in a $10 \mathrm{ml}$ test tube, a solution of $25.0 \mathrm{mg}$ of bismuth nitrate and $1.0 \%$ PVP was mixed with $0.5 \mathrm{ml}$ isopropyl alcohol and completed with distilled water to make up to a net volume of $9.0 \mathrm{ml}$ aqueous solution (A). After that, $5.0 \mathrm{mg}$ nystatin drug was dissolved in $1.0 \mathrm{ml}$ dimethyl sulfoxide (DMSO) to form an aqueous solution (B). Finally, solutions A and B were mixed at room temperature $\left(24.0 \pm 2.0^{\circ} \mathrm{C}\right.$ ) to a final ratio of $1: 5$ (nystatin : bismuth nitrate; $\mathrm{v} / \mathrm{v}$ ).

The resulting mixtures were irradiated by different gammaray doses (1.0, 3.0, 5.0, 10.0, 15.0, 20.0, 25.0, and 30.0 kGy). The optical characterization of the synthesized $\mathrm{Bi}_{2} \mathrm{O}_{3}$ NPsNystatin was performed by UV-Vis spectroscopy (JASCO V-560UV-Vis spectrophotometer) with respect to a negative control (the gamma-irradiated sample without bismuth nitrate).

A gamma-ray dose with high optical density (O.D.) was selected for further investigation. Additionally, the stability of 
the nystatin drug was examined after exposure to different gamma-rays doses (as mentioned-before).

A preliminary investigation was carried out to define the impact of the bismuth nitrate and nystatin drug concentrations regarding the $\mathrm{Bi}_{2} \mathrm{O}_{3}$ NPs production (after the exposure to the most-effective gamma-ray dose). The expected factorial investigation included two factors, i.e., bismuth nitrate and nystatin concentrations, over 12 levels (see Table 1). It must be noted that the main idea for the chosen factors used in the present study is that they had multiple significant influences on the $\mathrm{Bi}_{2} \mathrm{O}_{3}$ NPs production.

Bismuth nitrate solution (at different concentrations; see Table 1) was mixed with different concentrations of nystatin drug solution in addition to $0.2 \%$ isopropyl alcohol. The prepared solutions were stirred at room temperature $(24.0 \pm 2.0$ ${ }^{\circ} \mathrm{C}$ ) and finally exposed to varying gamma-ray doses (as determined from the last investigation).

\section{Characterization of the synthesized $\mathrm{Bi}_{2} \mathrm{O}_{3}$ NPs-Nystatin}

The crystallite sizes and the crystallinity of the synthesized $\mathrm{Bi}_{2} \mathrm{O}_{3}$ NPs-Nystatin were determined by XRD (XRD-6000, Shimadzu apparatus, SSI, Japan). The strength of the diffracted Xrays was recognized as per the diffraction angle $2 \theta$.

The common size and particle-size distribution of the $\mathrm{Bi}_{2} \mathrm{O}_{3}$ NPs-Nystatin were defined by dynamic light scattering (DLSPSS-NICOMP 380-USA). Additionally, the average nanostructure and the particle size of the synthesized $\mathrm{Bi}_{2} \mathrm{O}_{3}$ NPsNystatin were determined by high-resolution transmission electron microscopy (HRTEM, JEM2100, Jeol, Japan).

The surface and morphological features were examined by scanning electron microscopy (SEM, ZEISS, EVO-MA10, Germany). Also, EDX spectrum examination (BRUKER, Nano GmbH, D-12489, 410-M, Germany) was used to estimate the elemental composition, purity, and the relationship of each metal. SEM/EDX mapping method was applied for obtaining further information regarding the structure/simplicity, relationships, and the position of the metals in the synthesized $\mathrm{Bi}_{2} \mathrm{O}_{3}$ NPs-Nystatin.

Finally, FT-IR spectroscopy was performed to provide important data about the chemical functional groups present on the nystatin drug. The analyses were carried out using a JASCO FT-IR 3600 infra-red spectrometer and by using the $\mathrm{KBr}$ pellet method. It was determined at a wavenumber scale from 4000 to $400 \mathrm{~cm}^{-1}$.

\section{Antimicrobial activity of the synthesized $\mathrm{Bi}_{2} \mathrm{O}_{3}$ NPs-Nystatin}

The antimicrobial activities of the synthesized $\mathrm{Bi}_{2} \mathrm{O}_{3}$ NPsNystatin, polyvinylpyrrolidone (PVP), dimethyl sulfoxide (DMSO), nystatin drug, and bismuth ions were tested against some selected Candida species and pathogenic bacteria using the agar disc distribution method..$^{24}$

The examined microbes were taken from the culture collections at the Drug Microbiology Laboratory, Drug Radiation Research Department, NCRRT, Cairo, Egypt. The tested unicellular fungi were Candida albicans (1), Candida tropicalis (1), Candida tropicalis (22), Candida albicans (25), and Candida albicans (33), while the pathogenic bacteria included Grampositive (Bacillus cereus and Staphylococcus aureus; MRSA) and Gram-negative bacteria (Escherichia coli and Pseudomonas aeruginosa).

The tested bacterial inoculums were fixed with 0.5 McFarland (2-4) $\times 10^{7} \mathrm{CFU} \mathrm{ml}^{-1}$, and all the examined C. albicans and C. tropicalis were fixed with $0.5 \mathrm{McFarland}(3-5) \times 10^{8} \mathrm{CFU} \mathrm{ml}^{-1}$ after conducting UV-Vis spectrophotometry at $600 \mathrm{~nm} .^{25}$

Nystatin antifungal disc (NS 100; $100 \mu \mathrm{g} \mathrm{ml} \mathrm{m}^{-1}$ ) and amoxicillin/clavulanic acid (AMC; 20/10 $\mu \mathrm{g} \mathrm{ml} \mathrm{ml}^{-1}$ ) were examined as standard antibiotics. The growth restraint of the examined microbes was confirmed by the zone of inhibition (ZOI) after $24 \mathrm{~h}$ incubation. ${ }^{\mathbf{1 4}}$

The minimum inhibitory concentration (MIC) was assessed referring to the lowest concentration of $\mathrm{Bi}_{2} \mathrm{O}_{3}$ NPs-Nystatin that inhibited $99.0 \%$ of the bacterial and yeast growth. For this, the

Table 1 Experimental factorial design for the optimization of $\mathrm{Bi}_{2} \mathrm{O}_{3} \mathrm{NP}$ production using nystatin drug (NS) and bismuth nitrate after exposure to gamma rays at $20.0 \mathrm{kGy}$, their wavelength $(\mathrm{nm})$, and the corresponding optical density

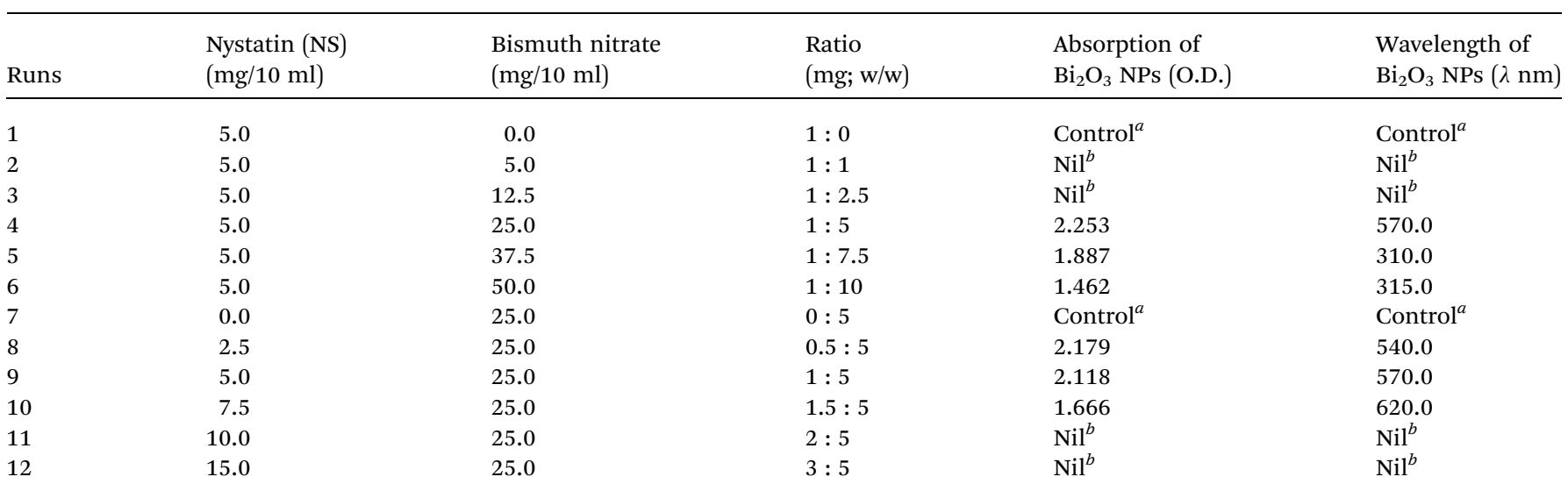

${ }^{a}$ Control was used to autozero the results from the set of other experiments that did not contain one of the precursors used for $\mathrm{Bi}_{2} \mathrm{O}_{3} \mathrm{NPs}-\mathrm{Nystatin}$ synthesis. ${ }^{b}$ Nil means there was no color change which confirms non-formation of $\mathrm{Bi}_{2} \mathrm{O}_{3}$ NPs-Nystatin. 
serial dilution method of a Luria-Bertani (LB) broth medium containing the tested microbes was applied using the ELISA plate method. ${ }^{26}$ The inoculums were fixed as mentioned-before in the first antimicrobial screening. ${ }^{25}$ Broth medium, DMSO, and PVP were used as a negative control, while the standard antibiotics (AMC and NS) were used as a positive control. Finally, serial dilutions of $\mathrm{Bi}_{2} \mathrm{O}_{3}$ NPs-Nystatin (starting with a concentration of $250 \mu \mathrm{g} \mathrm{ml}^{-1}$ ) were used. All the plates were incubated for $24 \mathrm{~h}$ at $36.0 \pm 1.0{ }^{\circ} \mathrm{C}$ and examined at $600 \mathrm{~nm} .{ }^{14}$

\section{Antibiofilm activity of the synthesized $\mathrm{Bi}_{2} \mathrm{O}_{3}$ NPs-Nystatin}

A qualitative study of the biofilm inhibition was performed as described by Christensen et al. ${ }^{27}$ Biofilm formation across the tube walls in the absence and presence of the synthesized $\mathrm{Bi}_{2} \mathrm{O}_{3}$ NPs-Nystatin was investigated.

The antibiofilm potential of the synthesized $\mathrm{Bi}_{2} \mathrm{O}_{3}$ NPsNystatin (at a ratio of $1: 5 \mathrm{w} / \mathrm{w}$ ) was examined against the most sensitive bacteria and Candida sp. with respect to the nontreated strain (control).

Briefly, $5.0 \mathrm{ml}$ of the nutrient broth medium was poured in to the tubes and the tested pathogenic bacteria and yeast cells were inoculated with 0.5 McFarland adjusted from 1-3 $\times 10^{7}$ CFU ml ${ }^{-1}$. Subsequently, they were incubated for $24 \mathrm{~h}$ at $35.0 \pm$ $2.0{ }^{\circ} \mathrm{C}$, and after that, the supernatant was discharged and all the tubes were mixed with phosphate buffer saline (PBS; pH 7.0) and finally dried..$^{28}$

The biofilms around and at the bottom of the tube walls were rinsed with $3.0 \mathrm{ml}$ sodium acetate $(3.5 \%)$ for $15 \mathrm{~min}$. and subsequently washed with de-ionized water. After that, $10.0 \mathrm{ml}$ crystal violet $(\mathrm{CV} ; 0.1 \%)$ was added to the biofilms that had developed inside the tubes (about $30 \mathrm{~min}$.) for the staining and finally the tubes were cleaned with de-ionized water. ${ }^{29}$

It is worth mentioning that, for the semi-quantitative antibiofilm investigation (inhibition\%), $3.0 \mathrm{ml}$ of the absolute ethanol was connected to the tubes to separate the colored biofilms, ${ }^{30}$ and after that, the O.D. of CV was measured using a UV-Vis spectrophotometer at a fixed wavelength $(570.0 \mathrm{~nm})$.

The biofilms inhibition percentage was determined using the following equation: ${ }^{14,27,30}$

$$
\begin{aligned}
& \text { Percentage of biofilms inhibition }(\%) \\
& =\frac{\text { O.D. of the control sample }- \text { O.D. of the treated sample }}{\text { O.D. of the control sample }} \\
& \quad \times 100
\end{aligned}
$$

Reaction mechanism using SEM/EDX analysis of the control and treated microbial cells

The susceptible Candida sp. (from the antibiofilm results; Table 4) were mixed with PBS and maintained with $3.0 \mathrm{ml}$ glutaraldehyde (3.0\%). Additionally, they were washed regularly with PBS and dried by different ethanol solutions (30.0\%, 50.0\%, $70.0 \%, 80.0 \%, 95.0 \%$, and $100.0 \%$ ) for $15 \mathrm{~min}$. at room temperature $\left(24.0 \pm 2.0{ }^{\circ} \mathrm{C}\right) .{ }^{30}$

The prepared Candida cells were set up on aluminum stumps for the imaging process. ${ }^{28,30}$ The surface morphology of the non-treated and treated Candida cells with the synthesized
$\mathrm{Bi}_{2} \mathrm{O}_{3}$ NPs-Nystatin was investigated by SEM to estimate the mode of action. The total elemental analysis of the tested Candida cells was estimated by EDX spectrum analysis.

\section{Statistical analysis}

The mathematical analysis of the data was performed by ONE WAY ANOVA (at $p<0.05$ ), least significant differences (LSD), and Duncan's multiple systems. ${ }^{31}$ The effects and data were examined and analyzed through SPSS software (version 15).

\section{Results and discussion}

\section{Synthesis and optimization of $\mathrm{Bi}_{2} \mathrm{O}_{3}$ NPs by nystatin and gamma-rays}

The synthesized $\mathrm{Bi}_{2} \mathrm{O}_{3}$ NPs-Nystatin solutions were a deep offwhite color due to the surface plasmon resonance (SPR) phenomenon. ${ }^{32}$ Fig. 1A displays the optimum gamma-ray doses used for the $\mathrm{Bi}_{2} \mathrm{O}_{3}$ NPs synthesis, which was confirmed using a UV-Vis spectrophotometer and found to be $20.0 \mathrm{kGy}$ with a high O.D. (2.751) at a wavelength of $465.0 \mathrm{~nm}$.

The synthesis of $\mathrm{Bi}_{2} \mathrm{O}_{3}$ NPs was assisted by the reduction of various conc. of bismuth nitrate solution (0.5, 12.5, 25.0, 37.5, and $50.0 \mathrm{mg} / 10 \mathrm{ml}$ ) in the presence of varying nystatin conc. $(0.5,2.5,5.0,7.5,10.0$, and $15.0 \mathrm{mg} / 10 \mathrm{ml})$ after mixing with PVP solution $(0.2 \%)$ and exposure to $20.0 \mathrm{kGy}$ gamma rays.

The results listed in Table 1 show that run (4) had the optimum concentrations $\left(2.5 \mathrm{mg} \mathrm{ml}^{-1}\right.$ bismuth nitrate and $0.5 \mathrm{mg} \mathrm{ml}^{-1} \mathrm{NS} ; 1: 5 \mathrm{w} / \mathrm{w}$ ), which was reflected by a high $\mathrm{Bi}_{2} \mathrm{O}_{3}$ NPs yield (2.253) at $570.0 \mathrm{~nm}$.

Table 1 shows that $\mathrm{Bi}_{2} \mathrm{O}_{3}$ NPs were not formed in runs 2 and 3 , where the concentration of nystatin was set at $0.5 \mathrm{mg} \mathrm{ml}^{-1}$ and the concentration of bismuth nitrate was 0.5 and $1.25 \mathrm{mg}$ $\mathrm{ml}^{-1}$, respectively which indicates that the concentration of bismuth nitrate was not sufficient for the $\mathrm{Bi}_{2} \mathrm{O}_{3}$ NPs production. In addition, there was a constant O.D. decrease from run 4 to run 6 when the nystatin concentration was set at $0.5 \mathrm{mg} \mathrm{ml}^{-1}$ and bismuth nitrate at $5.0 \mathrm{mg} \mathrm{ml}^{-1}$.

Also, Table 1 shows that there was a constant decline in the O.D. (runs 7 to 12) when the bismuth nitrate concentration was adjusted to $2.5 \mathrm{mg} \mathrm{ml}^{-1}$ and the nystatin concentration was changed from 0.25 to $1.5 \mathrm{mg} \mathrm{ml}^{-1}$, while both runs 11 and 12 involved a high concentration of nystatin, which antagonized the formation of $\mathrm{Bi}_{2} \mathrm{O}_{3}$ NPs.

The results confirmed that $\mathrm{Bi}_{2} \mathrm{O}_{3}$ NPs synthesis depended on the concentrations of bismuth nitrate and nystatin, although raising the concentration of both was ineffective. The optimum concentrations were $0.25 \mathrm{mg} \mathrm{ml}^{-1}$ of nystatin and $2.5 \mathrm{mg} \mathrm{ml}^{-1}$ of bismuth nitrate (run 8 ) and $0.50 \mathrm{mg} \mathrm{ml}^{-1}$ of nystatin and $2.5 \mathrm{mg} \mathrm{ml}^{-1}$ of bismuth nitrate (run 4).

On the other hand, the UV-Vis spectra of the starting materials (bismuth nitrate and nystatin) used in the $\mathrm{Bi}_{2} \mathrm{O}_{3}$ NPs synthesis are presented in Fig. 1B. The detectable wavelengths of both precursors were less than $300 \mathrm{~nm}$, which assisted the formation of $\mathrm{Bi}_{2} \mathrm{O}_{3}$ NPs at the wavelength of $465.0 \mathrm{~nm}$ (Fig. 1A).

Fig. 1C shows the stability of the nystatin solution $(0.5$ $\mathrm{mg} \mathrm{ml}$; run 4) following exposure to the corresponding 

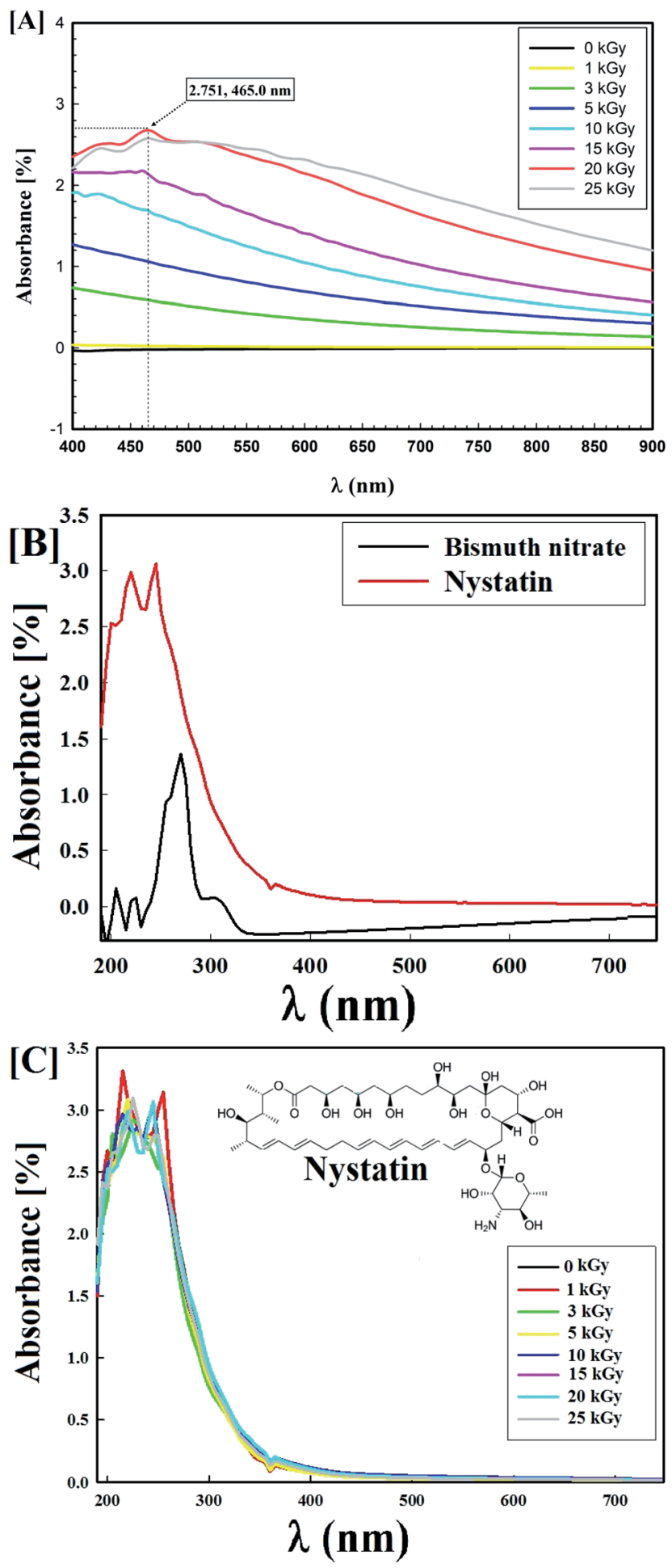

Fig. 1 UV-Vis spectra of the synthesized $\mathrm{Bi}_{2} \mathrm{O}_{3}$ NPs-Nystatin, where [A] the initial screening results to obtain the most potent gamma-ray dose to be used for $\mathrm{Bi}_{2} \mathrm{O}_{3}$ NPs-Nystatin synthesis, [B] UV-Vis spectra of the starting materials included in the $\mathrm{Bi}_{2} \mathrm{O}_{3}$ NPs-Nystatin synthesis, and [C] stability of the nystatin drug after exposure to different gamma-ray doses.

gamma-ray doses necessary for $\mathrm{Bi}_{2} \mathrm{O}_{3}$ NPs production. The results in Fig. $1 \mathrm{C}$ reveal that the nystatin was completely constant at all gamma-ray doses applied, which confirmed the opinion concerning the role of nystatin in the $\mathrm{Bi}_{2} \mathrm{O}_{3}$ NPs structure and stability. The common two peaks of nystatin appeared at 215.0 and $255.0 \mathrm{~nm},{ }^{33}$ and there was a slight decrease in the O.D. with the increase in gamma-ray doses.

This is in agreement with El-Sayyad et al., ${ }^{34}$ who worked on the incorporation of selenium NPs with the gentamycin drug (CN) and stated that the production of Se NPs-CN nano-drug depended on the sodium selenite and $\mathrm{CN}$ concentrations.

\section{Proposal reaction mechanism for $\mathrm{Bi}_{2} \mathrm{O}_{3}$ NPs synthesis}

When the nystatin solution $\left(0.5 \mathrm{mg} \mathrm{ml}^{-1}\right)$ was mixed with (2.5 $\mathrm{mg} \mathrm{ml}^{-1}$ ) bismuth nitrate solution (the common optimized state that resulted in a great $\mathrm{Bi}_{2} \mathrm{O}_{3}$ NPs yield; run 4 in Table 1) and exposed to $20.0 \mathrm{kGy}$ gamma rays, it produced the freeradical species $\left(\mathrm{OH}^{\circ}, \mathrm{H}^{*}, \mathrm{H}_{2} \mathrm{O}_{2}\right.$, and $\left.\mathrm{H}_{3} \mathrm{O}^{+}\right)$and solvated electrons $\left(\mathrm{e}_{\mathrm{aq}}{ }^{-}\right.$) (eqn (1)).

$$
\mathrm{H}_{2} \mathrm{O} \stackrel{\gamma \text {-radiolysis }}{\longrightarrow} \mathrm{OH}^{\cdot}+\mathrm{H}^{\cdot}+\mathrm{e}_{\mathrm{aq}}{ }^{-}+\mathrm{H}_{2} \mathrm{O}_{2}+\mathrm{H}_{3} \mathrm{O}^{+}
$$

$\mathrm{OH}^{*}$ radicals are powerful reducing agents and increase the oxidation of bismuth ions $\left(\mathrm{Bi}^{3+}\right)$ to $\mathrm{BiO}_{3}{ }^{-}$(eqn (2)).

$$
2 \mathrm{Bi}^{3+}+3 \mathrm{OH}^{\cdot} \rightarrow \mathrm{Bi}_{2} \mathrm{O}_{3}{ }^{-}+3 \mathrm{H}^{+}
$$

The produced bismuth oxide is first dimerized while incorporated with the remaining $\mathrm{Bi}_{2} \mathrm{O}_{3}{ }^{-}$and/or $\mathrm{Bi}^{3+}$ (eqn (3) \& (4)).

$$
\begin{gathered}
\mathrm{Bi}_{2} \mathrm{O}_{3}{ }^{-}+\mathrm{Bi}_{2} \mathrm{O}_{3}{ }^{-} \rightarrow 2 \mathrm{Bi}_{2} \mathrm{O}_{3}^{-} \\
\mathrm{Bi}_{2} \mathrm{O}_{3}{ }^{-}+\mathrm{Bi}^{3+} \rightarrow 2 \mathrm{Bi}_{2} \mathrm{O}_{3}^{-}
\end{gathered}
$$

The available radicals $\left(\mathrm{OH}^{*}\right.$ and $\left.\mathrm{H}^{*}\right)$ are adequate to separate hydrogen atoms from nystatin to create nystatin free radicals (secondary radicals $=\mathrm{C}_{47} \mathrm{H}_{74} \mathrm{NO}_{17}^{*}$; eqn (5)) then, the nystatin radicals react with $\mathrm{Bi}^{3+}$ to create $\mathrm{Bi}_{2} \mathrm{O}_{3}$ NPs and constant nystatin molecules (eqn (6)).

Finally, the formed nystatin can combine with the produced $\mathrm{Bi}^{0}$ (eqn (6)) though the oxygen atoms in the $\mathrm{OH}$ functional groups of the nystatin molecules to form more permanent $\mathrm{Bi}_{2} \mathrm{O}_{3}$ NPs, as displayed in eqn (7).

$$
\mathrm{C}_{47} \mathrm{H}_{75} \mathrm{NO}_{17}+\mathrm{OH}^{\cdot} \rightarrow \mathrm{C}_{47} \mathrm{H}_{74} \mathrm{NO}_{17}^{\cdot}+\mathrm{H}_{2} \mathrm{O}
$$

$2 \mathrm{C}_{47} \mathrm{H}_{74} \mathrm{NO}_{17}^{\cdot}+\mathrm{Bi}^{3+}+\mathrm{H}_{2} \mathrm{O}$

$$
\stackrel{\text { Reduction }}{\longrightarrow} \mathrm{Bi}^{0}+\left[\mathrm{C}_{47} \mathrm{H}_{75} \mathrm{NO}_{17}\right]_{2}+\mathrm{H}_{3} \mathrm{O}^{+}
$$

$\mathrm{C}_{47} \mathrm{H}_{75} \mathrm{NO}_{17}+\mathrm{Bi}^{0} \stackrel{\text { Stabilization and capping }}{\longrightarrow}\left[\mathrm{C}_{47} \mathrm{H}_{75} \mathrm{NO}_{17}\right]-\mathrm{Bi}$

The overall reaction is related to the generation of free electrons and radical groups and the presence of notable stabilizing agents (nystatin) that drive the reduction of $\mathrm{Bi}^{3+}$ to $\mathrm{Bi}^{0}$. 


\section{Characterization of the synthesized $\mathrm{Bi}_{2} \mathrm{O}_{3}$ NPs-Nystatin}

Shape, size, and distribution of $\mathrm{Bi}_{2} \mathrm{O}_{3}$ NPs-Nystatin: HRTEM and DLS investigations. To investigate the common particle size and the exact shape of the incorporated $\mathrm{Bi}_{2} \mathrm{O}_{3}$ NPs-Nystatin, an HRTEM study was carried out and the images were correlated with the DLS results to define the average distribution of the $\mathrm{Bi}_{2} \mathrm{O}_{3}$ NPs-Nystatin particle size. ${ }^{35}$

The HRTEM images showed round shapes with monodispersed $\mathrm{Bi}_{2} \mathrm{O}_{3}$ NPs-Nystatin (Fig. 2A) with a range from 18.40 to $34.99 \mathrm{~nm}$ and the average diameter was $27.97 \mathrm{~nm}$ as shown in the magnified image in Fig. $2 \mathrm{~B}$.

The average particle-size distribution was verified by the DLS method and determined as $40.74 \mathrm{~nm}$ in the $\mathrm{Bi}_{2} \mathrm{O}_{3}$ NPs incorporated with nystatin via applying $20.0 \mathrm{kGy}$ gamma rays as shown in Fig. 3.

It was noted that the DLS size area of the incorporated $\mathrm{Bi}_{2} \mathrm{O}_{3}$ NPs-Nystatin was higher than the HRTEM size; this is because DLS considers the hydrodynamic diameter where the incorporated $\mathrm{Bi}_{2} \mathrm{O}_{3}$ NPs-Nystatin are enveloped by water molecules, leading to the greater sizes of the incorporated $\mathrm{Bi}_{2} \mathrm{O}_{3}$ NPsNystatin. ${ }^{36}$

Crystal size and crystallinity determination of the $\mathrm{Bi}_{2} \mathrm{O}_{3}$ NPsNystatin: X-ray diffraction analysis. XRD was performed to determine the crystal structure and the common crystal size of the incorporated $\mathrm{Bi}_{2} \mathrm{O}_{3}$ NPs-Nystatin because it can show the status of the detected particles. ${ }^{37}$ The XRD results of the $\mathrm{Bi}_{2} \mathrm{O}_{3}$ NPs incorporated with nystatin after exposure to $20.0 \mathrm{kGy}$ gamma rays are displayed in Fig. 4.

Fig. 4 describes the crystal and/or amorphous compositions of the starting primary materials (bismuth nitrate, PVP, and nystatin) and the synthesized $\mathrm{Bi}_{2} \mathrm{O}_{3}$ NPs. It must be noted that the XRD results for bismuth nitrate represent the crystal construction,,$^{38}$ as shown in Fig. $4 \mathrm{~B}$, and the $2 \theta$ at $10.96^{\circ}$ and $21.10^{\circ}$ were similar to the amorphous type of PVP (Fig. 4A). ${ }^{39}$ Additionally the $2 \theta$ was detected at $13.89^{\circ}, 15.25^{\circ}, 20.24^{\circ}$, $21.91^{\circ}, 22.78^{\circ}$, and $26.58^{\circ}$ (Fig. 4C).

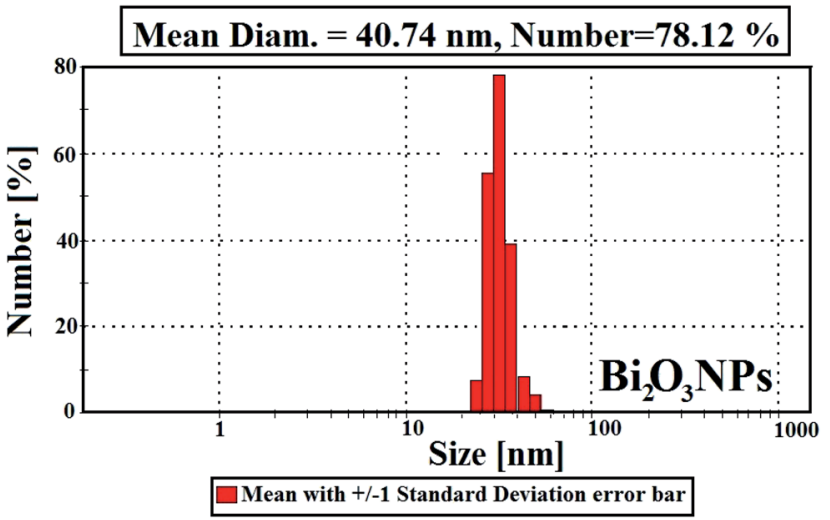

Fig. 3 Particle-size distribution for $\mathrm{Bi}_{2} \mathrm{O}_{3} \mathrm{NPs}-\mathrm{Nystatin}$ using the DLS technique.

The XRD data of the incorporated $\mathrm{Bi}_{2} \mathrm{O}_{3}$ NPs-Nystatin in Fig. 4D show the structure of the diffraction properties with $2 \theta$ at $28.15^{\circ}, 33.65^{\circ}, 46.17^{\circ}$, and $55.38^{\circ}$, which represent the Bragg's reflections at (111), (200), (220), and (311), respectively.

The presented peaks were similar with the Joint Committee on Powder Diffraction Standards (JCPDS) of $\mathrm{Bi}_{2} \mathrm{O}_{3}$ NPs (JCPDS file no 00-071-0465). ${ }^{40}$ This means that the incorporated $\mathrm{Bi}_{2} \mathrm{O}_{3}$ NPs-Nystatin stayed as a crystal and displayed the face-centered cubic (fcc) crystalline composition. There were additional amorphous peaks for PVP and nystatin (Fig. 4D) that was included in the assembly and stability of the $\mathrm{Bi}_{2} \mathrm{O}_{3}$ NPs, but their strength was less than that identified in Fig. 4A and C.

Additionally, the average crystallite size of the incorporated $\mathrm{Bi}_{2} \mathrm{O}_{3}$ NPs-Nystatin was defined by applying the WilliamsonHall (W-H) equation, ${ }^{41,42}$ and was observed to be $30.54 \mathrm{~nm}$ for $\mathrm{Bi}_{2} \mathrm{O}_{3}$ NPs produced by nystatin via 20.0 kGy gamma-ray application according to eqn (8).

$$
\beta \cos \theta=\frac{k \lambda}{D_{\mathrm{W}-\mathrm{H}}}+4 \varepsilon \sin \theta
$$

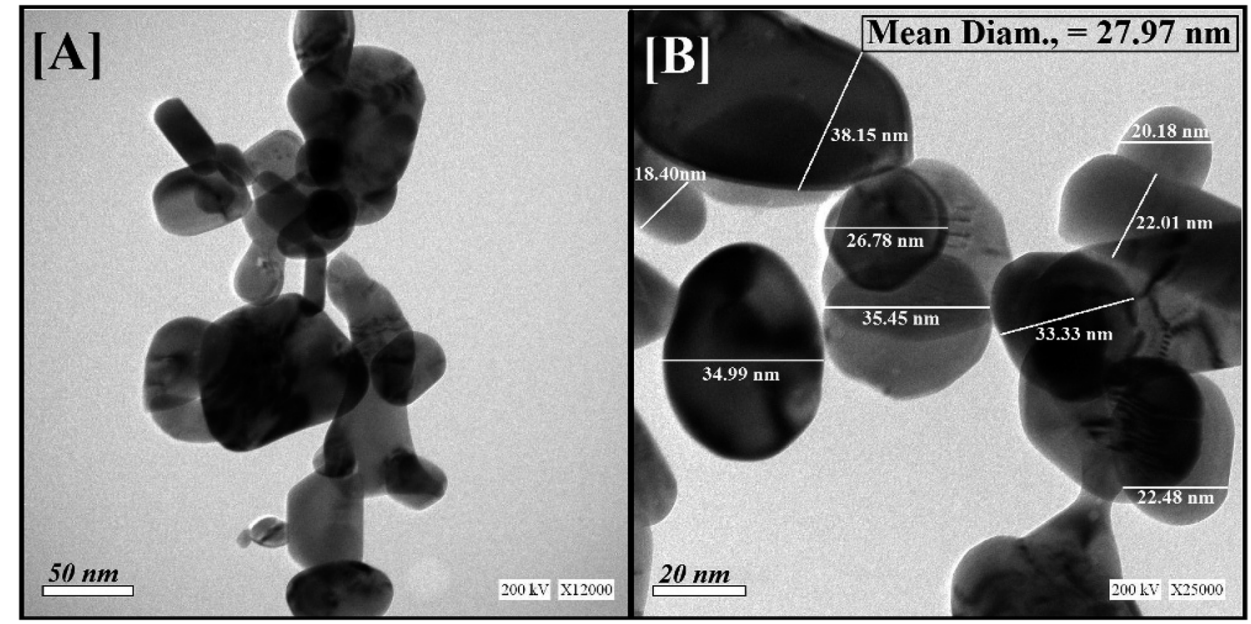

Fig. 2 Shape, nano-structure, and mean particle-size determination by HR-TEM for $\mathrm{Bi}_{2} \mathrm{O}_{3} \mathrm{NPs}$-Nystatin, where [A] presents the low magnification $(50 \mathrm{~nm})$ and $[B]$ the high magnification $(20 \mathrm{~nm})$ images. 

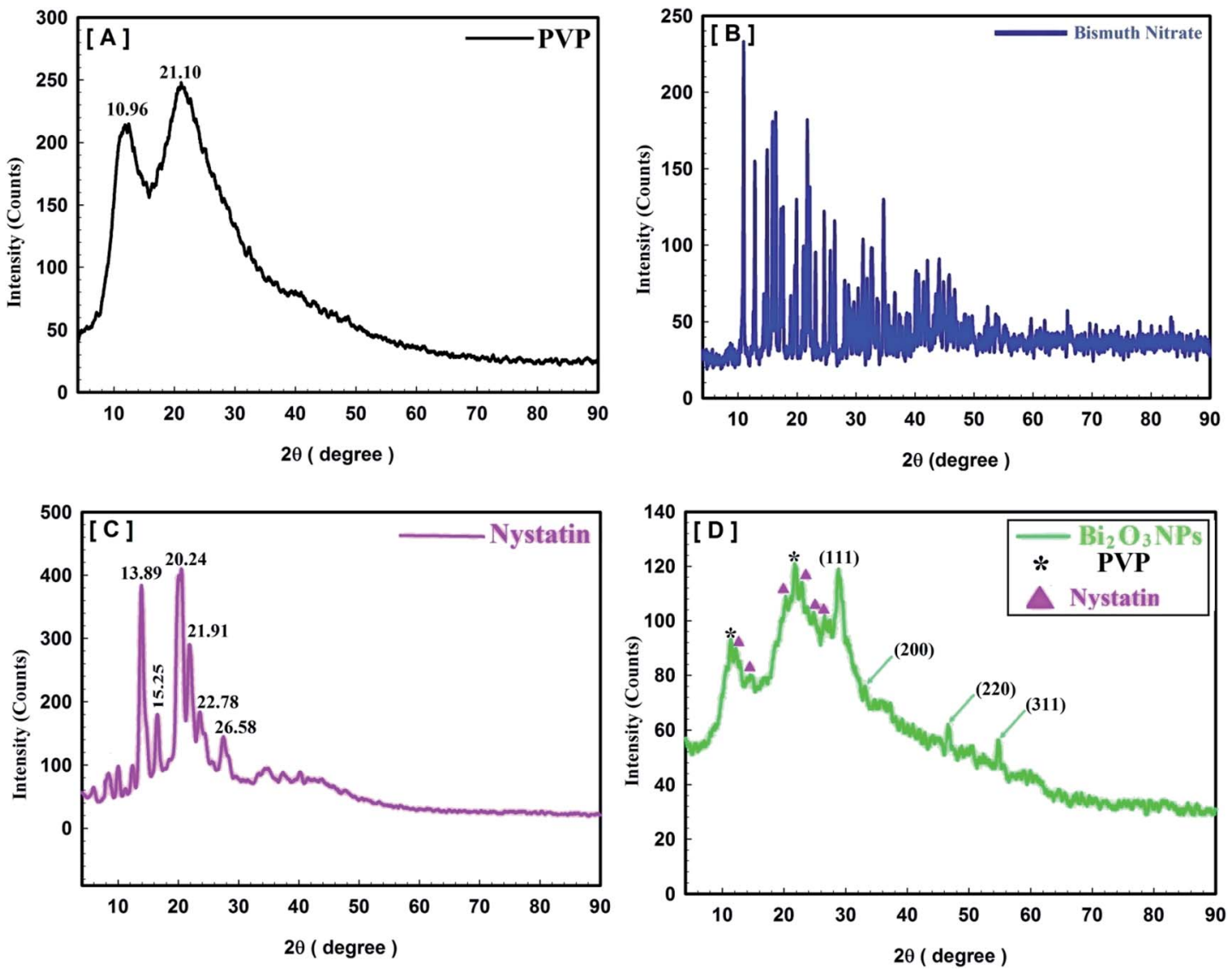

Fig. 4 Crystallinity and crystal-size determination using XRD analysis, where [A] polyvinylpyrrolidone (PVP), [B] bismuth nitrate, [C] nystatin drug (NS), and [D] the synthesized $\mathrm{Bi}_{2} \mathrm{O}_{3}$ NPs-Nystatin nano-drug.

where $D_{\mathrm{W}-\mathrm{H}}$ is the average crystallite size, $\lambda$ is the X-ray wavelength, $\beta$ is the full-width at half maximum, $\varepsilon$ is the strain of the samples, $\theta$ is the Bragg's angle, and $k$ is a constant.

Surface morphology and elemental composition of $\mathrm{Bi}_{2} \mathrm{O}_{3}$ NPs-Nystatin: SEM and EDX analyses. The surface characteristics and morphology of the incorporated $\mathrm{Bi}_{2} \mathrm{O}_{3}$ NPs-Nystatin were investigated by SEM technique. Fig. 5A illustrates the SEM image of the synthesized $\mathrm{Bi}_{2} \mathrm{O}_{3}$ NPs-Nystatin at $20.0 \mathrm{kGy}$ gamma-ray irradiation including the different grain sizes and the equivalent round shape. It can be noticed that the $\mathrm{Bi}_{2} \mathrm{O}_{3} \mathrm{NPs}$ were distributed beyond the nystatin drug, which shows them as brilliant NPs linked near by the antibiotic units.

EDX is an analytical method used for the elemental investigation or the qualitative chemical validation of synthesized metal oxide NPs. ${ }^{37,42}$ EDX analysis was used to establish the elemental composition of the synthesized $\mathrm{Bi}_{2} \mathrm{O}_{3}$ NPs-Nystatin and its capacity for determining the purity of the synthesized $\mathrm{Bi}_{2} \mathrm{O}_{3}$ NPs as represented in Fig. 5B.

The synthesized $\mathrm{Bi}_{2} \mathrm{O}_{3}$ NPs exhibited notable absorption peaks related to the bismuth element at 0.25 and $2.35 \mathrm{keV}$. The lack of further elemental peaks and a large amount of bismuth in the spectra confirmed the purity of the bismuth element. The presence of carbon, oxygen, and nitrogen peaks in the examined samples was due to the presence of stabilizers or the capping factor (nystatin drug, Fig. 5B).
Mapping analysis of the elements in $\mathrm{Bi}_{2} \mathrm{O}_{3}$ NPs-Nystatin. The mapping models of the elements present in $\mathrm{Bi}_{2} \mathrm{O}_{3}$ NPs-Nystatin are displayed in Fig. 6. The images are defined as $\mathrm{C}, \mathrm{O}, \mathrm{Bi}$, and $\mathrm{N}$ for the incorporated $\mathrm{Bi}_{2} \mathrm{O}_{3}$ NPs-Nystatin.

The displayed atoms were related to the distribution to $\mathrm{Bi}, \mathrm{C}$, $\mathrm{O}$, and $\mathrm{N}$ atoms. Moreover, the $\mathrm{C}, \mathrm{O}$, and $\mathrm{N}$ atoms were in agreement with the nystatin drug. Subsequently according to the given image, the synthesized $\mathrm{Bi}_{2} \mathrm{O}_{3}$ NPs-Nystatin (bright red NPs) was developed regularly across the nystatin atoms (C, O, and $\mathrm{N}$ ).

Surface bonding and functional groups analysis; FTIR analysis of $\mathrm{Bi}_{2} \mathbf{O}_{3}$ NPs-Nystatin. FTIR investigations were performed to determine the interaction between $\mathrm{Bi}_{2} \mathrm{O}_{3}$ NPs and the antifungal nystatin drug (Fig. 7). The FTIR spectrum of the nystatin drug had absorption bands at 3377.20, 2935.12, $1705.36,1442.56,1322.0$, and $1063.84 \mathrm{~cm}^{-1}$, and the absorption bands for the synthesized $\mathrm{Bi}_{2} \mathrm{O}_{3}$ NPs-Nystatin were at 3336.16, $2931.52,1644.88,1442.55,1322.0,1011.08$, and $617.44 \mathrm{~cm}^{-1}$, as shown in Fig. 7.

The broad peak at $3336.16 \mathrm{~cm}^{-1}$ was assigned to the $-\mathrm{OH}$ of the hydroxyl group and -NH stretching, while the peak at $2931.52 \mathrm{~cm}^{-1}$ was attributed to the asymmetric and symmetric $-\mathrm{CH}$ vibrations of the $-\mathrm{CH}_{2}$ group. The peak at $1644.88 \mathrm{~cm}^{-1}$ was related to $-\mathrm{C}=\mathrm{O}$ stretching of the ester group. 


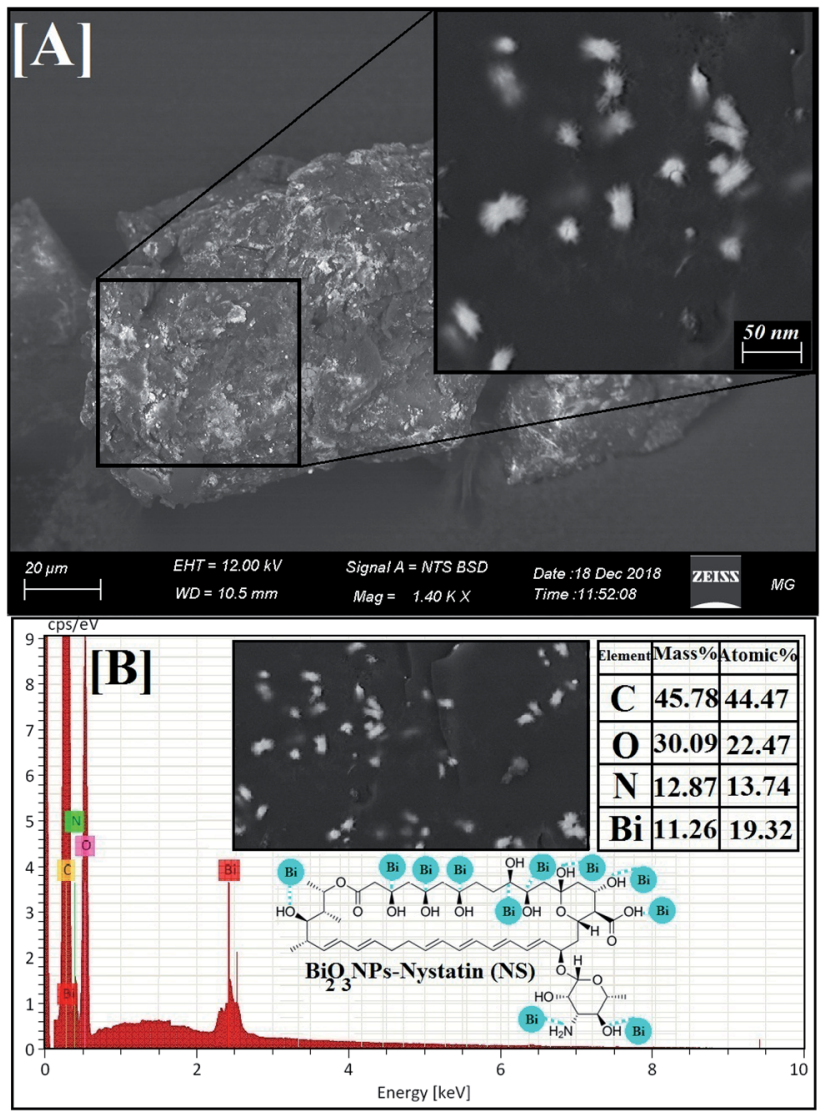

Fig. 5 Surface morphology and elemental analysis of the synthesized $\mathrm{Bi}_{2} \mathrm{O}_{3}$ NPs-Nystatin, where [A] SEM image, [B] EDX elemental analysis.

The peak located at $1442.55 \mathrm{~cm}^{-1}$ was designated to $-\mathrm{CH}_{3}$. A further band at $1322.0 \mathrm{~cm}^{-1}$ was related to $-\mathrm{COO}^{-}$. Also, the peaks located at $1011.08 \mathrm{~cm}^{-1}$ were due to polyene sequences. A definite peak at $617.44 \mathrm{~cm}^{-1}$ was identified in the FTIR of $\mathrm{Bi}_{2} \mathrm{O}_{3}$ NPs-Nystatin, which may be associated with the conjugation and attraction of $\mathrm{Bi}_{2} \mathrm{O}_{3}$ NPs beside the hydroxyl group in the nystatin drug as $\mathrm{Bi}-\mathrm{O} .{ }^{37}$ The FTIR results in the present study were similar to those in recently published research studies. ${ }^{23,43,44}$

According to the FTIR results in the present research, it was concluded that the intensity of all the detected peaks was reduced in the FTIR of $\mathrm{Bi}_{2} \mathrm{O}_{3}$ NPs-Nystatin. This may be because of the interaction of $\mathrm{Bi}_{2} \mathrm{O}_{3} \mathrm{NPs}$, the $-\mathrm{OH}$, and other functional groups present in the nystatin drug.

It was noted that the nystatin drug may combine with $\mathrm{Bi}_{2} \mathrm{O}_{3}$ NPs either by the available amine residue and/or by the electrostatic attraction among the carboxylate groups, which hold a negative charge ${ }^{45}$ so they support the $\mathrm{Bi}_{2} \mathrm{O}_{3}$ NPs from aggregation through the influence of the $\mathrm{O}$ and/or $\mathrm{N}$ atoms present in the nystatin drug.

In vitro antimicrobial activity of the synthesized $\mathrm{Bi}_{2} \mathrm{O}_{3}$ NPsNystatin. It was obvious from the disc agar distribution method (as a screening procedure) that the incorporated $\mathrm{Bi}_{2} \mathrm{O}_{3}$ NPsNystatin displayed a qualitative antimicrobial potential toward all the tested bacterial strains and Candida pathogens. The in vitro ZOI result verified that the $\mathrm{Bi}_{2} \mathrm{O}_{3}$ NPs-Nystatin exhibited an elevated antibacterial activity against $E$. coli $(17.0 \mathrm{~mm} \mathrm{ZOI}$; Fig. 8A) and S. aureus; MRSA (13.0 mm ZOI; Fig. 8B), as displayed in Table 2.

It worth noting that the antibacterial potency of the $\mathrm{Bi}_{2} \mathrm{O}_{3}$ NPs-Nystatin was significantly more powerful than bismuth nitrate, PVP, DMSO, the nystatin drug alone, and the standard antimicrobial agents (AMC).

It is also necessary to note that the synthesized $\mathrm{Bi}_{2} \mathrm{O}_{3}$ NPsNystatin were active against Gram-negative bacteria more than Gram-positive. Note, the cell wall constituents in Gram-negative bacteria contain principally little layers of lipopolysaccharide, lipid, and peptidoglycan. On the other hand, the cell wall of Gram-positive incorporate very solid peptidoglycan forms. ${ }^{\mathbf{4 6}}$

Additionally, the synthesized $\mathrm{Bi}_{2} \mathrm{O}_{3}$ NPs-Nystatin were shown to incorporate promising antifungal factors as they exhibited tremendous antifungal efficiency against $C$. tropicalis (22) (15.0 mm ZOI; Fig. 8C) and C. albicans (25) (15.0 mm ZOI; Fig. 8D), as recorded in Table 2.

There is a relationship between the characteristics of the synthesized $\mathrm{Bi}_{2} \mathrm{O}_{3}$ NPs-Nystatin and the antimicrobial effects discussed. The $\mathrm{Bi}_{2} \mathrm{O}_{3}$ NPs-Nystatin were stable because of the PVP polymer applied, their reduced crystal size $(30.54 \mathrm{~nm}$; Fig. 4D), and separated spherical form with a particle size within the nano-scale (27.97 nm; Fig. 2), as well as their uniformity (EDX; Fig. 5B) and pattern of mono-dispersed highly-distributed NPs (40.74 nm; Fig. 3), which served as an essential objective for enhancing the antimicrobial potency of the $\mathrm{Bi}_{2} \mathrm{O}_{3}$ NPs-Nystatin at low concentration $(1: 5 \mathrm{w} / \mathrm{w})$, against all the tested bacterial and Candida sp.

The $\mathrm{Bi}_{2} \mathrm{O}_{3}$ NPs-Nystatin displayed individual physical and chemical properties better than the traditional organic and synthesized antimicrobial agents, such as decreased crystal sizes, reduced average particle size, more stability, and a higher potency for interaction with more pathogenic bacteria and Candida sp., thus consequently, increasing their antimicrobial potential. $^{37}$

The MIC results of the $\mathrm{Bi}_{2} \mathrm{O}_{3}$ NPs-Nystatin against all the tested pathogenic bacteria and Candida sp. ranged from $3.9 \mu \mathrm{g}$ $\mathrm{ml}^{-1}$ nystatin: $8.4 \mu \mathrm{g} \mathrm{ml}^{-1} \mathrm{Bi}_{2} \mathrm{O}_{3} \mathrm{NPs}$, to $0.24 \mu \mathrm{g} \mathrm{ml}^{-1}$ nystatin: $0.52 \mu \mathrm{g} \mathrm{ml} \mathrm{mi}^{-1} \mathrm{Bi}_{2} \mathrm{O}_{3} \mathrm{NPs}$, as mentioned in Table 2. The $\mathrm{Bi}_{2} \mathrm{O}_{3}$ NPs-Nystatin possessed a promising MIC of $0.24 \mu \mathrm{g} \mathrm{ml} \mathrm{ml}^{-1}$ nystatin: $0.52 \mu \mathrm{g} \mathrm{ml} \mathrm{ml}^{-1} \mathrm{Bi}_{2} \mathrm{O}_{3}$ NPs against $S$. aureus; MRSA, B. cerus, C. albicans (25), and C. tropicalis (1).

The $\mathrm{Bi}_{2} \mathrm{O}_{3}$ NPs-Nystatin's size was not the only parameter indicating the antimicrobial characteristics, but other features, such as their mono-dispersity, simplicity, stability, and their appearance, should be considered.

The results from similar studies ${ }^{23,47-49}$ of the antimicrobial behavior of the incorporated $\mathrm{Bi}_{2} \mathrm{O}_{3}$ NPs-Nystatin against some bacteria and fungi-causing infectious diseases are introduced in Table 3. The encouraging antimicrobial potential of the synthesized $\mathrm{Bi}_{2} \mathrm{O}_{3}$ NPs-Nystatin in our research was due to their small particle and/or crystal sizes, extensive purity, superior stability by using the PVP polymer, and the incorporation with the nystatin drug, which enhanced their synergistic impact.

The antibiofilm activity of the incorporated $\mathrm{Bi}_{2} \mathrm{O}_{3}$ NPsNystatin. Biofilm production was identified in various microbes 


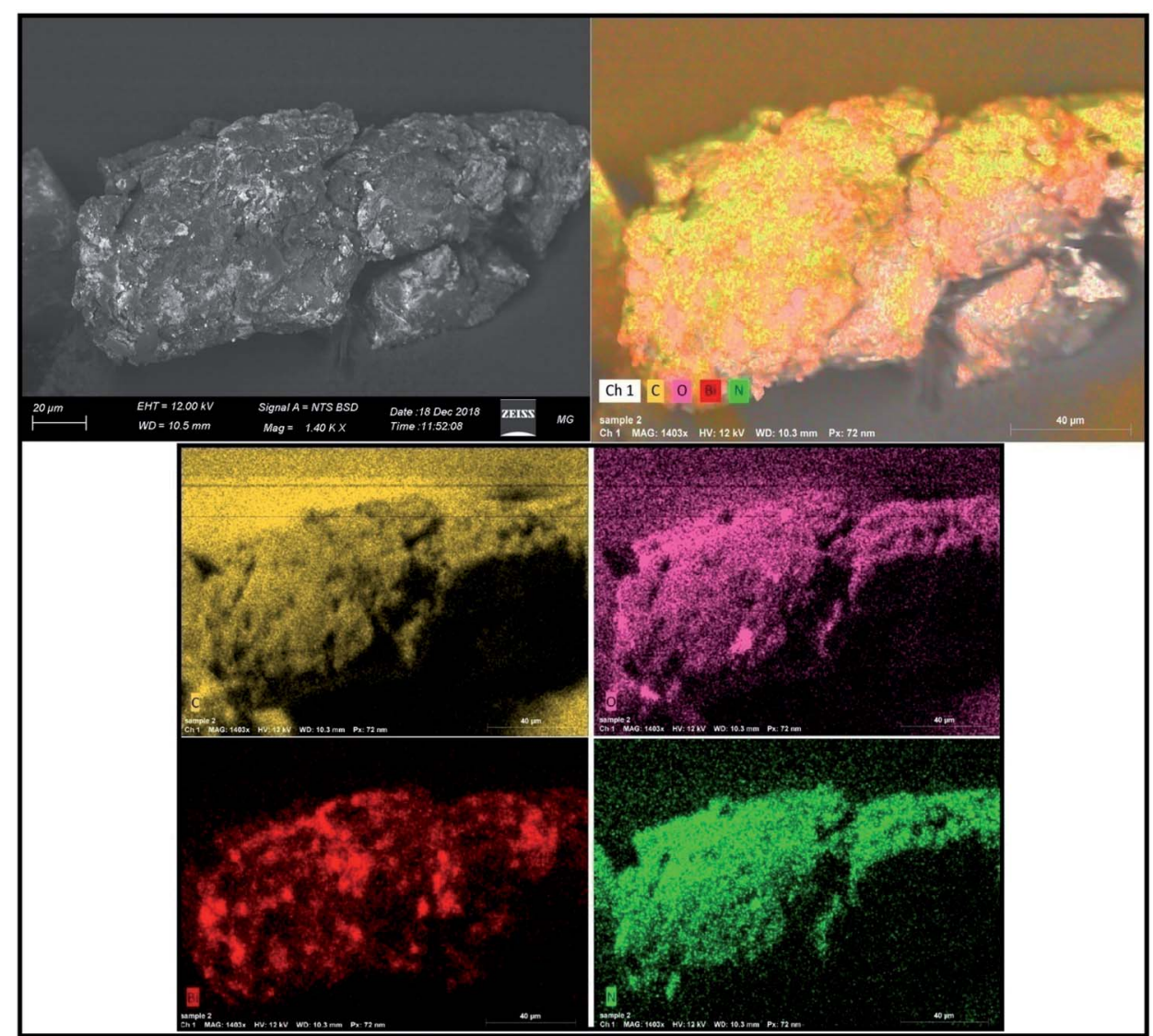

Fig. 6 SEM/EDX mapping images of the synthesized $\mathrm{Bi}_{2} \mathrm{O}_{3}$ NPs-Nystatin.

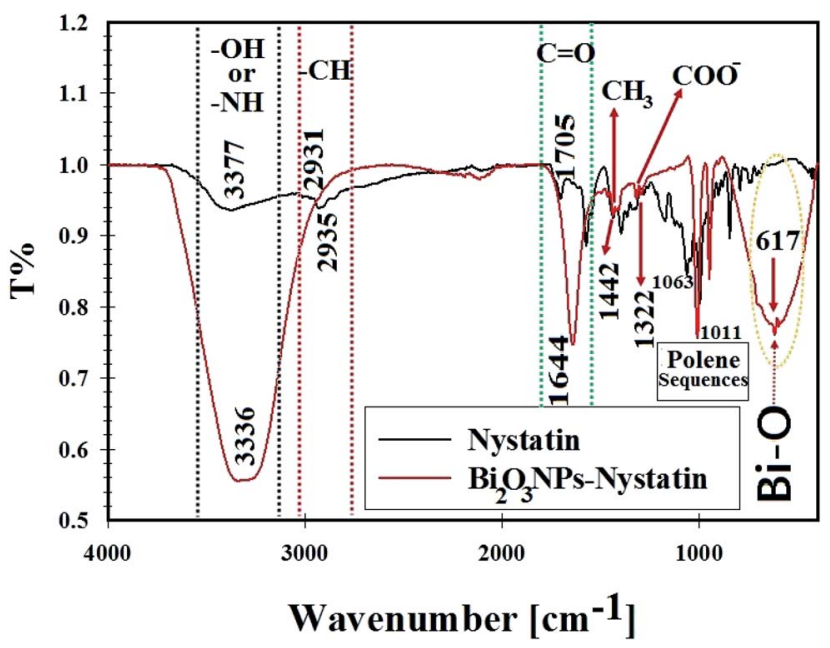

Fig. 7 FT-IR spectra, surface bonding, and functional groups analysis for nystatin (NS) and the synthesized $\mathrm{Bi}_{2} \mathrm{O}_{3}$ NPs-Nystatin.

in the absence and presence of $\mathrm{Bi}_{2} \mathrm{O}_{3}$ NPs-Nystatin as assessed by the tube technique..$^{28,30}$

C. albicans (1) in the absence of $\mathrm{Bi}_{2} \mathrm{O}_{3}$ NPs-Nystatin formed a thick whitish-yellow matt across the air-liquid interface, which adhered entirely to the tube walls and gave a blue color when stained with crystal violet. Also, a dark blue suspension was formed following dissolving the $\mathrm{CV}$ by pure ethanol, as presented in Fig. 9A.

The C. albicans (1) tubes treated with $\mathrm{Bi}_{2} \mathrm{O}_{3}$ NPs-Nystatin (1.95 NS: $4.2 \mathrm{Bi} ; \mu \mathrm{g} \mathrm{ml}{ }^{-1}$ ), revealed a negative biofilm formation. The color of the adherent cells was light blue after CV staining, as shown in Fig. 9A. The same conditions were described for the biofilm repression of E. coli and Bacillus cereus, as displayed in Fig. 9B and C, respectively.

To determine the inhibition percentage (\%) of the biofilm created by the examined pathogens, a UV-Vis spectrophotometer (set at $570.0 \mathrm{~nm}$ ) was applied. The O.D. estimated the subsequent dissolving of the stained biofilm through ethanol. ${ }^{29}$

Table 4 records the repression percentages of the biofilm generation by the tested bacteria and Candida sp. The highest restraint\% was noted for C. albicans (1) (94.15\%), followed by $E$. coli $(84.85 \%)$, and B. cereus $(84.79 \%)$ after treatment with $\mathrm{Bi}_{2} \mathrm{O}_{3}$ NPs-Nystatin (1.95 NS: $4.2 \mathrm{Bi} ; \mu \mathrm{g} \mathrm{ml}{ }^{-1}$ ).

The synthesized $\mathrm{Bi}_{2} \mathrm{O}_{3}$ NPs-Nystatin was applied to repress biofilm development in its constant adhesion step (also identified as the primary stage). ${ }^{50}$ However, the mechanistic behavior of the incorporated $\mathrm{Bi}_{2} \mathrm{O}_{3}$ NPs upon biofilm development has yet to be confirmed.

The difference in the inhibitory percentage may be described by many aspects, like antimicrobial potency, biosorption (due to the high surface area of the incorporated $\mathrm{Bi}_{2} \mathrm{O}_{3}$ NPs-Nystatin), physical features $\left(\mathrm{Bi}_{2} \mathrm{O}_{3}\right.$ NPs-Nystatin size; $\left.27.97 \mathrm{~nm}\right)$, 


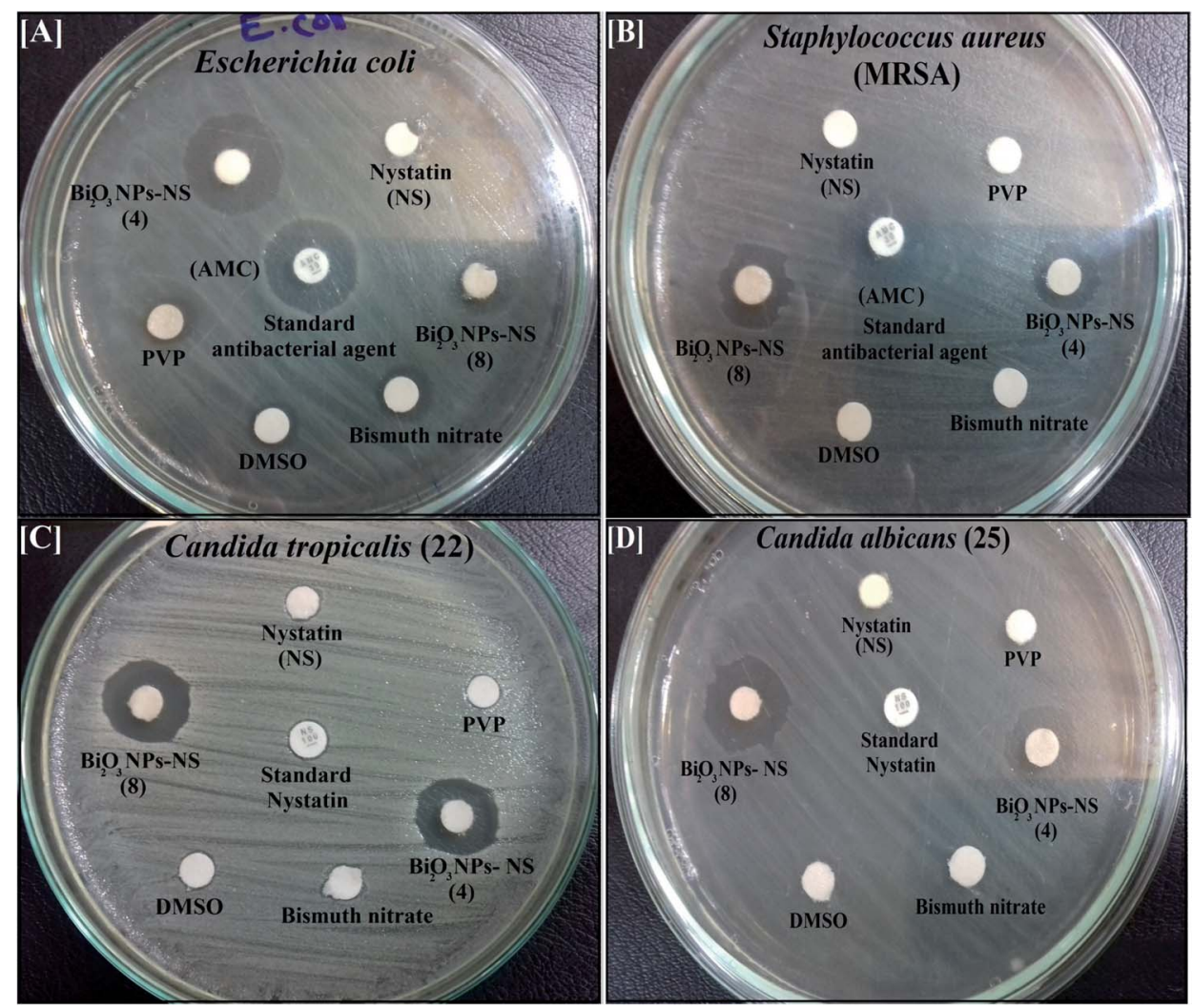

Fig. 8 Antimicrobial activity of the synthesized $\mathrm{Bi}_{2} \mathrm{O}_{3}$ NPs-Nystatin (two different samples; see Table 2), nystatin, bismuth nitrate, DMSO, and PVP against [A] Escherichia coli, [B] Staphylococcus aureus, [C] Candida tropicalis (22), and [D] Candida albicans (25) as ZOI.

penetration capabilities, and distinct chemical attributes that influence the relationship and synergy of the $\mathrm{Bi}_{2} \mathrm{O}_{3}$ NPsNystatin with the Candida biofilm. ${ }^{51}$

It was clear that the $\mathrm{Bi}_{2} \mathrm{O}_{3}$ NPs-Nystatin restrained C. albicans biofilm expansion by a factor of more than $98 \%$ at (1.95 NS: 4.2 $\mathrm{Bi} ; \mu \mathrm{g} \mathrm{ml} \mathrm{ml}^{-1} \mathrm{Bi}_{2} \mathrm{O}_{3}$ NPs-Nystatin (MIC results; Table 2). The exopolysaccharide (the principal precursors of biofilm production) formation was hindered so $C$. albicans could not produce a biofilm..$^{28}$ Our anti-biofilm research is comparable to the findings of Ashajyothi et al. ${ }^{50}$ who stated that the synthesized ZnO NPs displayed a biofilm hindrance $\%$ of $10.7 \%$ against $P$. aeruginosa following $18 \mathrm{~h}$ incubation.

$\mathrm{Bi}_{2} \mathrm{O}_{3}$ NPs-Nystatin mode of action against Candida sp. using SEM/EDX technique. Moreover, to describe the antibiofilm impact of $\mathrm{Bi}_{2} \mathrm{O}_{3}$ NPs-Nystatin, we suggested a reaction mechanism for the synthesized $\mathrm{Bi}_{2} \mathrm{O}_{3}$ NPs-Nystatin toward $C$. albicans (1) that produced a biofilm. The mode of action was investigated using SEM and EDX examination. ${ }^{52}$ Through the SEM technique, the Candida cell morphologies could be observed in the cases of the non-treated and treated cells with the $\mathrm{Bi}_{2} \mathrm{O}_{3}$ NPs-Nystatin.

Initially, the yeast populations (control without $\mathrm{Bi}_{2} \mathrm{O}_{3}$ NPsNystatin treatment) were developed regularly and showed the definite normal cellular morphology with the usual cell surface, budding appearance, and a developed biofilm, as explained in Fig. 10A.
By comparison, the morphological modifications were recognized in C. albicans (1) cells following treatment with the incorporated $\mathrm{Bi}_{2} \mathrm{O}_{3}$ NPs-Nystatin at $1.95 \mathrm{NS}: 4.2 \mathrm{Bi} \mu \mathrm{g} \mathrm{ml} l^{-1}$ (Fig. 10B). An obvious surface cell break and consequent deformation and failure to form budding properties of the treated C. albicans (1) upon $\mathrm{Bi}_{2} \mathrm{O}_{3}$ NPs-Nystatin addition were noted. Furthermore, the number of viable cells and biofilm production were repressed. SEM analysis revealed that the $\mathrm{Bi}_{2} \mathrm{O}_{3}$ NPs-Nystatin were directed to effect Candida cell wall depreciation (Fig. 10B). ${ }^{52}$ The EDX elemental study showed the appearance of $\mathrm{Bi}$ and $\mathrm{O}$ at the shrinking cell membrane and on the outside surface of the treated C. albicans (1), which confirmed $\mathrm{Bi}_{2} \mathrm{O}_{3}$ NPs-Nystatin action toward the yeast cells (Fig. 10B; inset).

One potential reason for $\mathrm{Bi}_{2} \mathrm{O}_{3}$ NPs-Nystatin action upon $C$. albicans (1) could be connected to the elevated surface area of the $\mathrm{Bi}_{2} \mathrm{O}_{3}$ NPs-Nystatin providing more reliable interactions among the negatively-charged Candida cell walls, as shown in Fig. 10B. Additional studies revealed that the metal oxide NPs combine with pathogens by their electrostatic potential and defeat bacteria by layer separation. ${ }^{53}$

A recent report examined the interaction between $\mathrm{Bi}_{2} \mathrm{O}_{3}$ NPs and the tested microbes and found that the attraction takes place by electrostatic attraction leading to the membrane leakages. ${ }^{53}$ Further research revealed that the metal oxide NPs attack the microbes and increase the oxidative pressure, ${ }^{54}$ which quickly changes the yeast cells due to the high level of ROS production. 


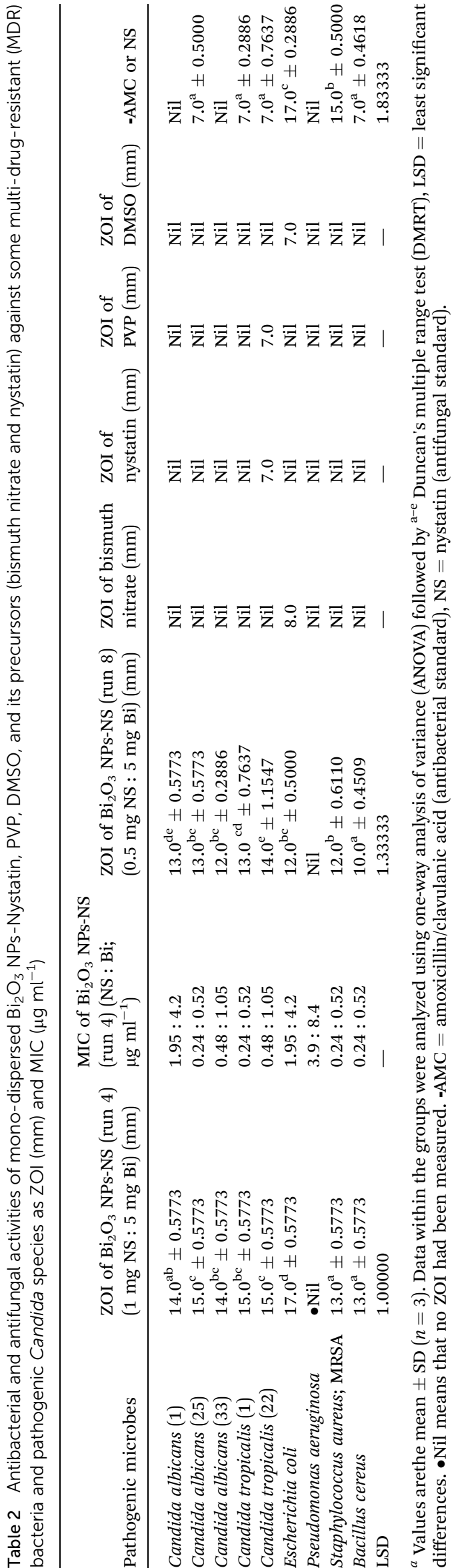

The free radicals generation is influenced by the prominent reduction in oxygen by the electron change above the oxygen atom through electron transport in the mitochondria. ${ }^{53}$

It must be mentioned that the suggested reaction mechanism of metal oxide NPs toward the pathogenic bacteria and Candida cells was explained in our earlier studies ${ }^{14}$ and is schematically drawn in Fig. 11.

The mode of action included four mechanisms that describe the effect of $\mathrm{Bi}_{2} \mathrm{O}_{3}$ NPs-Nystatin toward Candida cells. It begins with the adhesion of $\mathrm{Bi}_{2} \mathrm{O}_{3}$ NPs-Nystatin near the surface of the Candida cells. Following that, $\mathrm{Bi}^{3+}$ ions inside the Candida cells split the intracellular organic molecules (DNA and mitochondria). Then the cellular toxicity, like oxidative stress, is created by the formation of ROS. Finally, $\mathrm{Bi}_{2} \mathrm{O}_{3}$ NPs-Nystatin stimulates the Candida signal transduction pathways, in addition to the performance of nystatin which alters the action of beta-glycan synthase and ergosterol construction and subsequently alters the permeability of the cell membrane and the transportation of ions inside the Candida cells. ${ }^{55}$

Toxicity of the $\mathrm{Bi}_{2} \mathbf{O}_{3}$ NPs. Nano-materials have attracted much attention in diverse areas extending from biomedicine to manufacturing due to their outstanding physicochemical characteristics and purposes, leading to spreading human susceptibility to different NPs. Bismuth-based composites have been generally accepted for technical, pharmaceutical and biomedical purposes. Although the toxicity of the bismuth composites is considered at times, there is a severe absence of data regarding their toxicity and outcomes in the nano-scale on personal health and the climate. ${ }^{56}$

The genotoxic effects of $\mathrm{Bi}_{2} \mathrm{O}_{3}$ NPs at various concentrations $\left(12.5,25.0,50.0,75.0\right.$, and $\left.100.0 \mu \mathrm{g} \mathrm{ml}^{-1}\right)$ were investigated on the root cells of Allium cepa. The results indicated that the exposure to $\mathrm{Bi}_{2} \mathrm{O}_{3}$ NPs considerably enhanced the mitotic index (except at 12.5 $\mu \mathrm{g} \mathrm{ml}{ }^{-1}$ ) and the total chromosomal differences, while confused anaphase-telophase, anaphase bridges, and stickiness chromosome laggards were recognized in anaphase-telophase cells. A notable improvement in DNA destruction was also recognized at all $\mathrm{Bi}_{2} \mathrm{O}_{3}$ NPs concentrations (except at $12.5 \mu \mathrm{g} \mathrm{ml}^{-1}$ ). ${ }^{57}$

In another study, ${ }^{56}$ the toxic impacts of $\mathrm{Bi}_{2} \mathrm{O}_{3}$ NPs on the liver (HepG2 cell), intestine (Caco-2 colorectal cell), kidney (NRK-52E epithelial cell), and lung (A549 lung cell) were studied. It was mentioned that $\mathrm{Bi}_{2} \mathrm{O}_{3}$ NPs reduced the cell viability by intruding on the mitochondrial and lysosomal purposes in HepG2, Caco2, NRK-52E, and A549 cells in a dose-subject way. The $\mathrm{IC}_{50}$ values of $\mathrm{Bi}_{2} \mathrm{O}_{3}$ NPs were counted at $35.10-96.50 \mu \mathrm{g} \mathrm{ml} l^{-1}$.

Furthermore, Kovriznych et al. ${ }^{58}$ stated that the acute toxic amount $\left(\mathrm{LC}_{50}\right.$ evaluation) of $\mathrm{Bi}_{2} \mathrm{O}_{3}$ NPs was less than $1.6 \mu \mathrm{g} \mathrm{ml}^{-1}$ in adult fish and zebra fish eggs. The cytotoxicity of $\mathrm{Bi}_{2} \mathrm{O}_{3} \mathrm{NPs}$ may be associated with several distinct agents, like oxidative destruction in living systems.

New studies report that $\mathrm{Bi}_{2} \mathrm{O}_{3}$ NPs influence oxidative stress by elevating reactive oxygen species, membrane lipid peroxidation, and reducing intracellular glutathione (GSH). ${ }^{59}$ Additionally, Yang Luo et al. ${ }^{60}$ reported that Bi NPs are non-toxic at a concentration of $0.5 \mathrm{nM}$, but at elevated concentration (50 $\mathrm{nM}$ ) they induced cytotoxicity and killed about $45 \%$ of HeLa cells. 
Table 3 Comparative antimicrobial studies between different synthesized $\mathrm{Bi}_{2} \mathrm{O}_{3} \mathrm{NPs}$

\begin{tabular}{|c|c|c|c|c|}
\hline Methods of $\mathrm{Bi}_{2} \mathrm{O}_{3}$ NPs preparation & $\begin{array}{l}\text { Average particle } \\
\text { size (nm) }\end{array}$ & Starting concentration $\left(\mu \mathrm{g} \mathrm{ml}{ }^{-1}\right)$ & $\begin{array}{l}\text { Antimicrobial activity (ZOI; mm) } \\
\text { and/or (MIC; } \mu \mathrm{g} \mathrm{ml} \mathrm{ml}^{-1} \text { ) }\end{array}$ & References \\
\hline $\begin{array}{l}\text { Green synthesis using nystatin } \\
\text { (NS) drug and gamma rays }\end{array}$ & $27.97 \mathrm{~nm}$ & $\begin{array}{l}1 \mathrm{mg} \text { NS : } 5 \mathrm{mg} \mathrm{Bi} / \mathrm{ml} \text { for } \mathrm{ZOI} \text { and } \\
\text { MIC }\end{array}$ & $\begin{array}{l}15.0 \mathrm{~mm} \text { ZOI and } 0.24 \mathrm{NS}: 0.52 \mathrm{Bi} \\
\mu \mathrm{g} \mathrm{ml} \mathrm{MIC}^{-1} \mathrm{MI}\end{array}$ & Our research \\
\hline $\begin{array}{l}\text { Biogenic synthesis by fungal } \\
\text { melanin pigment and gamma rays }\end{array}$ & $29.82 \mathrm{~nm}$ & $0.8 \mu \mathrm{g} \mathrm{ml}^{-1}$ for ZOI and MIC & $20.0 \mathrm{~mm} \mathrm{ZOI}$ and $0.4 \mu \mathrm{g} \mathrm{ml}^{-1} \mathrm{MIC}$ & 23 \\
\hline $\begin{array}{l}\text { Chemical synthesis of bismuth } \\
\text { dimercaptopropanol } \\
\text { nanoparticles (BisBAL NPs) }\end{array}$ & $18.7 \mathrm{~nm}$ & $0.1-100 \mu \mathrm{M}$ for $\mathrm{ZOI}$ and $\mathrm{MIC}$ & $\begin{array}{l}\text { BisBAL NPs inhibited } S . \text { mutans } \\
\text { and } S . \text { gordonii growth by more } \\
\text { than } 70 \% \text { at } 0.1 \mu \mathrm{M} \text { and, MIC of } \\
\text { for } S . \text { mutans, } S . \text { gordonii was } 5 \mu \mathrm{M} \text {, } \\
\text { and } C . \text { albicans was } 10 \mu \mathrm{M}\end{array}$ & 47 \\
\hline $\begin{array}{l}\text { Biological synthesis of bismuth } \\
\text { nanoparticles by Delftia sp. }\end{array}$ & $40-120 \mathrm{~nm}$ & $1000 \mu \mathrm{g}$ per disc for ZOI & $\begin{array}{l}27.0 \mathrm{~mm} \text { ZOI and } 1280 \mu \mathrm{g} \mathrm{ml}^{-1} \\
\text { MIC }\end{array}$ & 48 \\
\hline $\begin{array}{l}\text { Biosynthesis of elemental } \\
\text { bismuth oxide nanoparticles by } \\
\text { Serratia marcescens }\end{array}$ & $\leq 5 \mathrm{~nm}$ & $40-140 \mu \mathrm{g} \mathrm{ml} \mathrm{m}^{-1}$ & $100 \mu \mathrm{g} \mathrm{ml}^{-1} \mathrm{MIC}$ & 49 \\
\hline
\end{tabular}
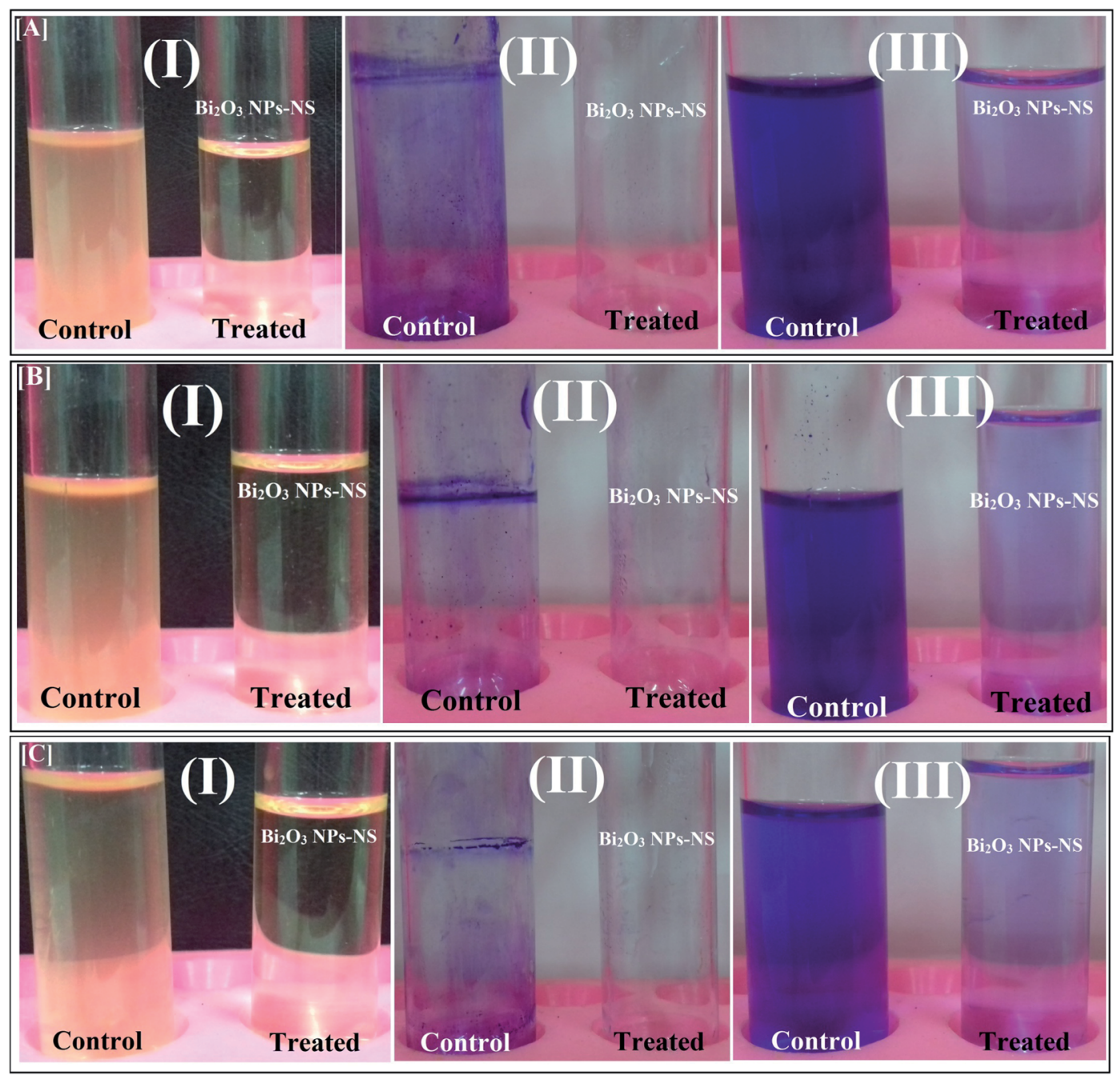

Fig. 9 Antibiofilm activity of the synthesized $\mathrm{Bi}_{2} \mathrm{O}_{3}$ NPs-Nystatin using the tube method against [A] Candida albicans (1) [B] Escherichia coli, and [C] Bacillus cereus, where the steps are reported as follows: (I) growth of the bacterial and yeast cells and biofilm formation (rings) without treatment with the synthesized $\mathrm{Bi}_{2} \mathrm{O}_{3} \mathrm{NPs}-\mathrm{Nystatin}(\mathrm{NS})$ and the inhibition of bacterial and yeast growth after treatment with $\mathrm{Bi}_{2} \mathrm{O}_{3} \mathrm{NPs}-\mathrm{Nystatin}$; (II) staining of the adherent bacterial and yeast cells with crystal violet and (III) removing and dissolving the adherent bacterial and yeast cells by ethanol for semi-quantitative biofilm inhibition (\%) determination (as shown in Table 4). 
Table 4 Semi-quantitative inhibition\% of the biofilm formation for non-treated and treated pathogenic bacteria and $\mathrm{Candida}$ species with $\mathrm{Bi}_{2} \mathrm{O}_{3}$ NPs-Nystatin ${ }^{a}$

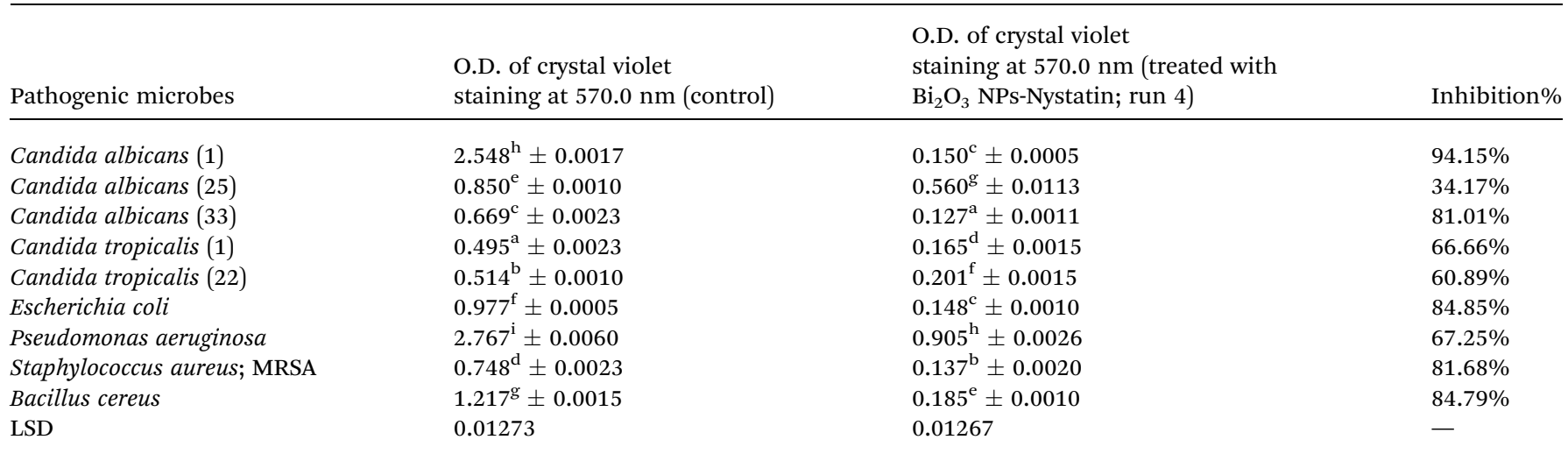

${ }^{a}$ Values are the mean $\pm \mathrm{SD}(n=3)$. Data within the groups were analyzed using one-way analysis of variance (ANOVA) followed by ${ }^{\text {a-i }}$ Duncan's multiple range test (DMRT), and LSD = least significant differences.

Our study assumed that the synthesized $\mathrm{Bi}_{2} \mathrm{O}_{3}$ NPs-Nystatin could serve as a bactericidal and strong fungicidal agent, and would not create any deadly impact on the human system. Animal kidney cells were exposed to $2 \mathrm{mM} \mathrm{Bi}_{2} \mathrm{O}_{3} \mathrm{NPs}$ for one day and their cytotoxic influence was not verified. ${ }^{22}$ Although the $\mathrm{Bi}_{2} \mathrm{O}_{3}$ NPs represent a pleasant approach to reduce infections, more investigation is needed to ensure their proper application for human society. ${ }^{23}$
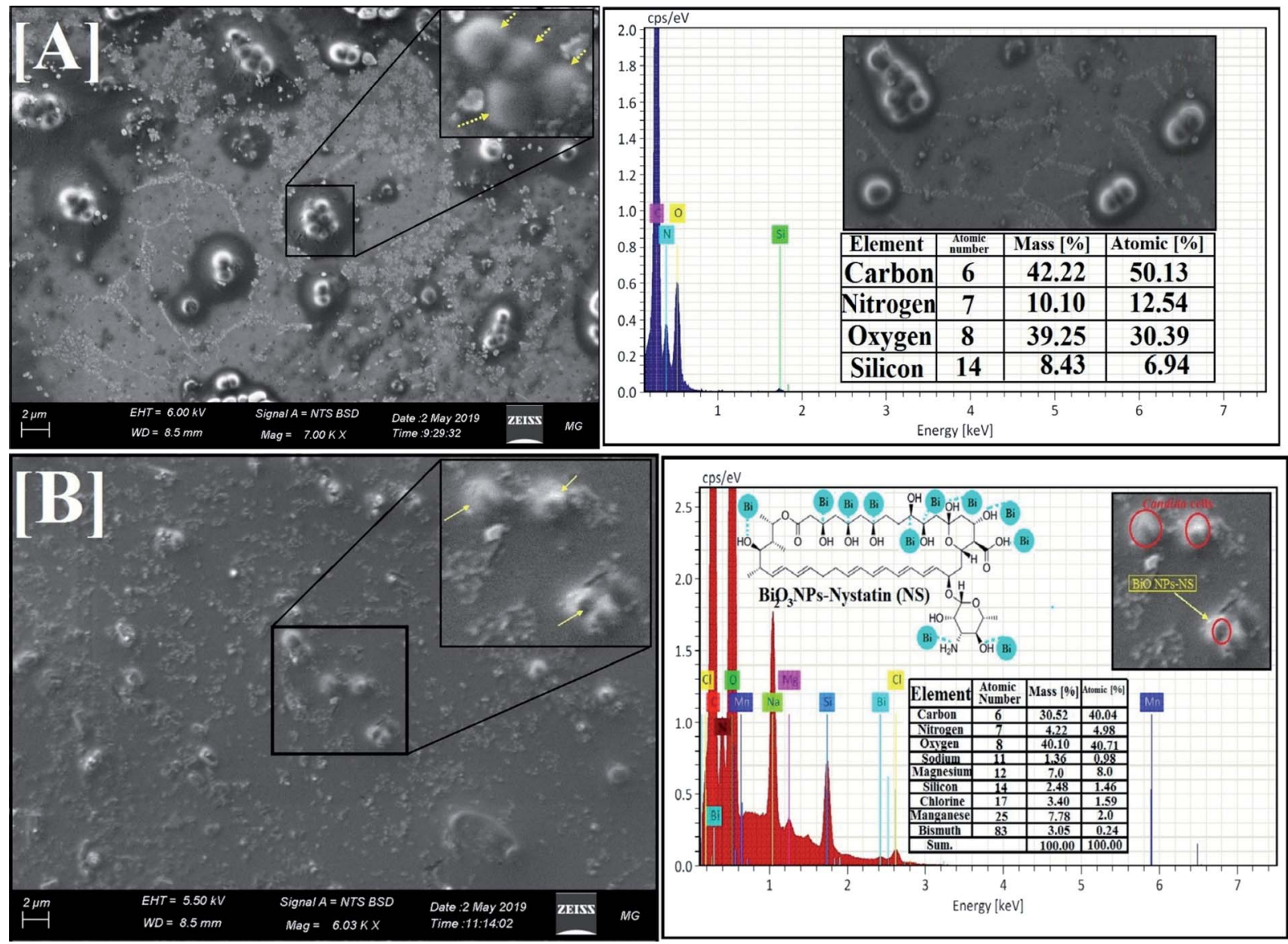

Fig. $10 \mathrm{SEM}$ images and the corresponding EDX elemental analysis of Candida albicans (1), where [A] normal Candida cells without $\mathrm{Bi}_{2} \mathrm{O}_{3} \mathrm{NPs}-$ Nystatin treatment (yellow arrows for normal budded Candida cells), and [B] depressed, and deformed Candida cells under the influence of $\mathrm{Bi}_{2} \mathrm{O}_{3}$ NPs-Nystatin (yellow arrows represent the complete lysis of the Candida cells and loss of budding formation). 


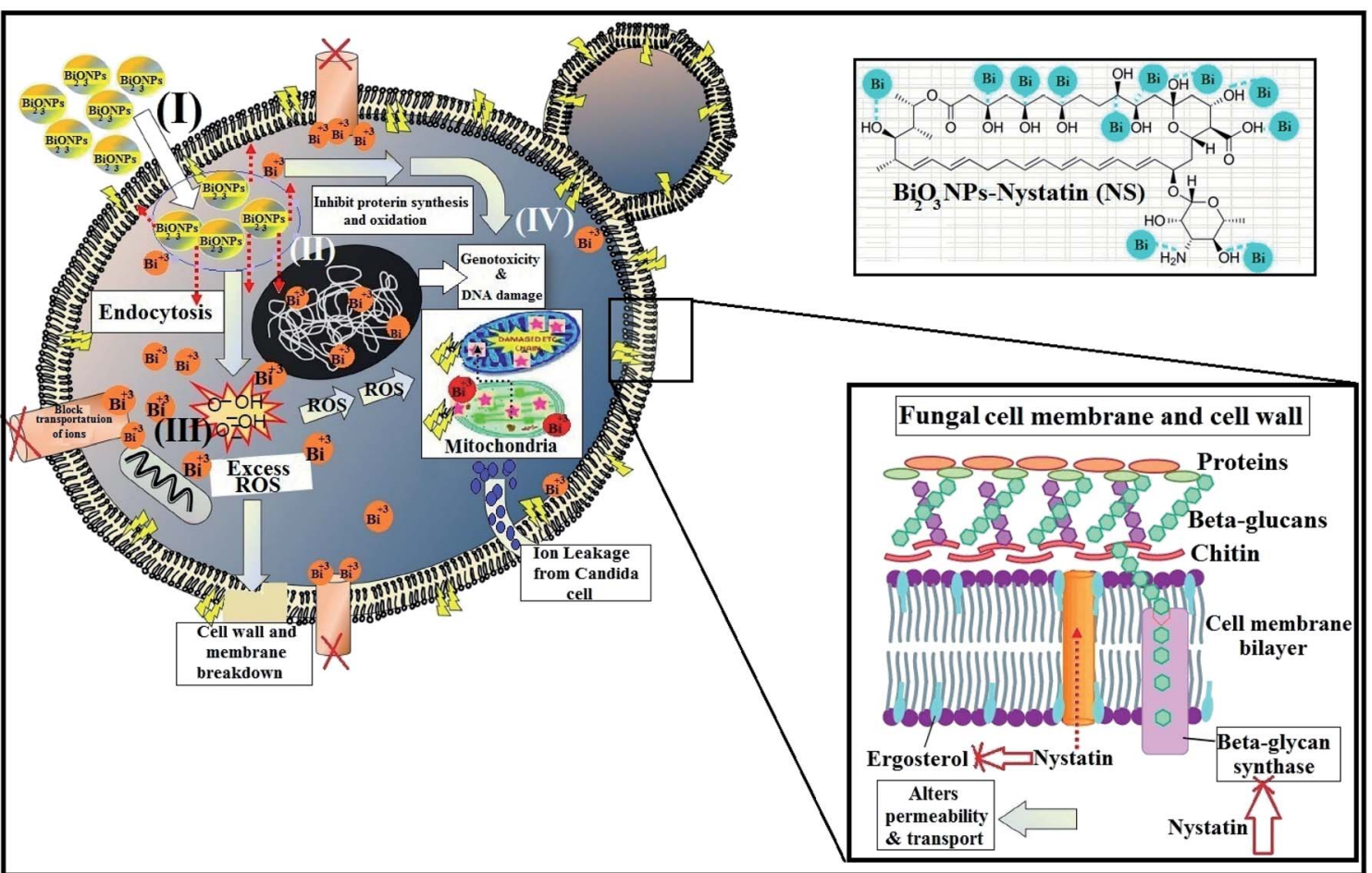

Fig. 11 The four common mechanisms of the antimicrobial activity of $\mathrm{Bi}_{2} \mathrm{O}_{3} \mathrm{NPs}$-Nystatin, where (I) $\mathrm{Bi}_{2} \mathrm{O}_{3} \mathrm{NPs}$ adhere to the surface of the pathogenic Candida cell and affect the membrane structure and penetrate the cell membrane due to their small size, (II) $\mathrm{Bi}_{2} \mathrm{O}_{3} \mathrm{NPs}_{\mathrm{siffuse}}$ inside the Candida cells and associate with Candida organelles and bio-molecules, thereby changing the cellular mechanism and producing geno-

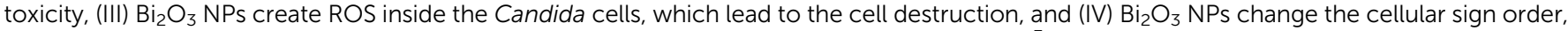
eventually inducing cell necrosis. Additionally, the $\mathrm{Bi}_{2} \mathrm{O}_{3} \mathrm{NPs}$ may assist as a carrier to release $\mathrm{Bi}^{3+}$ ions more efficiently to the Candida cytoplasm and layer, in which the proton motive force may reduce the $\mathrm{pH}$ (below $\mathrm{pH} 3.5$ ), which improves $\mathrm{Bi}^{3+}$ ions release. Nystatin alters the action of beta-glycan synthase and ergosterol construction and subsequently alters the permeability of the cell membrane and the transportation of ions inside the Candida cells.

The interesting thing about inorganic NPs are their high surface-to-volume degrees, many structural advantages, several applications, and nano-scale size, which represent infinite dynamic forms to connect with living forms, like pathogenic bacteria and fungi. This is the significant difference between different NPs and traditional organic antimicrobial agents, which in turn could help minimize the risk of developing antimicrobial resistance. ${ }^{23}$

The results obtained in this study propose unique, efficient, low-cost, and broad-spectrum antimicrobial factors. The $\mathrm{Bi}_{2} \mathrm{O}_{3}$ NPs could be used at low concentration in foodstuff, pharmaceutical applications, dental supplements, labs, disinfectant, clinics, and geriatric and pediatric hospitals primarily for Candida sp. infection treatment.

\section{Conclusion}

In this study, the synergistic effect of $\mathrm{Bi}_{2} \mathrm{O}_{3} \mathrm{NPs}$ and nystatin to govern "Candida" germination and biofilms creation was verified. The study also reported an encouraging method to restrain the pathogenic Candida sp. and some examined bacteria using $\mathrm{Bi}_{2} \mathrm{O}_{3}$ NPs-Nystatin. This planned method could not only dramatically reduce the administered nystatin dose but could also improve its potency. An eco-friendly and cost-efficient approach was applied to synthesize the $\mathrm{Bi}_{2} \mathrm{O}_{3}$ NPs using nystatin drug and polyvinylpyrrolidone (PVP) as stabilizing agents after exposure to $20.0 \mathrm{kGy}$ gamma-ray irradiation. Joining $\mathrm{Bi}_{2} \mathrm{O}_{3}$ NPs with the nystatin antifungal agent is a modular approach that could be implemented as a strategy for enhancing the currently ineffective nystatin drug. The average particle size and surface morphology of the incorporated $\mathrm{Bi}_{2} \mathrm{O}_{3}$ NPs-Nystatin were exhibited to be mono-dispersed and rounded with an average size of $27.79 \mathrm{~nm}$. EDX elemental analysis confirmed the growth of pure $\mathrm{Bi}_{2} \mathrm{O}_{3}$ NPs-Nystatin without any impurities. In addition, the antimicrobial potential in terms of ZOI and MIC toward different Candida sp. and some pathogenic bacteria was studied. The incorporated $\mathrm{Bi}_{2} \mathrm{O}_{3}$ NPs-Nystatin at low concentration (MIC $=0.24: 0.52 ; \mathrm{NS}: \mathrm{Bi} \mu \mathrm{g} \mathrm{ml}^{-1}$ ) restrained the development and attack of C. albicans. The current study considers that the small crystal size $(\approx 30 \mathrm{~nm})$ and high purity and stability play the main roles in the success of the combination of $\mathrm{Bi}_{2} \mathrm{O}_{3}$ NPs-Nystatin, at reduced concentrations, toward all the examined bacteria and Candida cells. Furthermore, the antibiofilm potential of the incorporated $\mathrm{Bi}_{2} \mathrm{O}_{3}$ NPsNystatin was extremely encouraging $(94.15 \%$ inhibition toward C. albicans (1)). The morphological modifications of the Candida cells after treatment with $\mathrm{Bi}_{2} \mathrm{O}_{3}$ NPs-Nystatin (at a ratio of $1: 5 \mathrm{w} / \mathrm{w}$ ) were conceived as noticeable alterations in the cell hardness and visible surface cell brokenness. Also, the consequent deformation and loss of budding features of $C$. albicans 
(1) were limited after treatment with the synthesized $\mathrm{Bi}_{2} \mathrm{O}_{3}$ NPsNystatin. The novel synthetic process for the $\mathrm{Bi}_{2} \mathrm{O}_{3}$ NPs-Nystatin is a promising method for possible use in manufacturing, pharmaceutical, and biomedical purposes and for managing dangerous infections, particularly candidoses. However, future work in this area needs to continue to cover the safety of using these small-sized materials and their activity over the course of application. In addition, investigation of the mechanism of the interactions across the genetic level of this type of nano-drug with current and other types of bacteria and pathogenic fungal strains is an essential element needed to complete the work.

\section{Conflicts of interest}

The authors declare that they have no conflict of interests.

\section{Acknowledgements}

The authors would like to thank the Nanotechnology Research Unit (P. I. Prof. Dr Ahmed I. El-Batal), Drug Microbiology Lab., Drug Radiation Research Department, NCRRT, Egypt, for financing and supporting this study under the project "Nutraceuticals and Functional Foods Production by using Nano/ Biotechnological and Irradiation Processes". Also, the authors would like to thank the Chemical Engineering Department, Military Technical College, Egyptian Armed Forces, and Zeiss microscope team at Cairo, Egypt, for their invaluable support of this study.

\section{References}

1 J.-A. Van Burik, D. Myerson, R. W. Schreckhise and R. A. Bowden, J. Clin. Microbiol., 1998, 36, 1169-1175.

2 T. L. Dawson Jr, Cell Host Microbe, 2019, 25, 345-347.

3 S. B. Wey, M. Mori, M. A. Pfaller, R. F. Woolson and R. P. Wenzel, Arch. Intern. Med., 1988, 148, 2642-2645.

4 M. Pfaller and D. Diekema, J. Clin. Microbiol., 2004, 42, 44194431.

5 L. de Repentigny, Curr. Opin. Microbiol., 2004, 7, 324-329.

6 F. L. Mayer, D. Wilson and B. Hube, Virulence, 2013, 4, 119128.

7 S. C. Deorukhkar, S. Saini and S. Mathew, Int. J. Microbiol., 2014, 2014, 456878.

8 J. L. R. Tudela and D. W. Denning, Lancet Infect. Dis., 2017, 17, 1111-1113.

9 S. Deorukhkar and S. Saini, Int. J. Med. Sci. Publ. Health, 2013, 2, 533-539.

10 K. M. Rice, G. K. Ginjupalli, N. D. Manne, C. B. Jones and E. R. Blough, Nanotechnology, 2019, 30, 372001.

11 C. Cavaleiro, E. Pinto, M. Gonçalves and L. Salgueiro, J. Appl. Microbiol., 2006, 100, 1333-1338.

12 M. Martin and R. Dinsdale, Br. J. Oral Surg., 1982, 20, 294298.

13 G. Ritchie, A. Fletcher, D. Main and A. Prophet, J. Prosthet. Dent, 1969, 22, 185-200.
14 M. Abd Elkodous, G. S. El-Sayyad, I. Y. Abdelrahman, H. S. El-Bastawisy, A. E. Mohamed, F. M. Mosallam, H. A. Nasser, M. Gobara, A. Baraka, M. A. Elsayed and A. I. El-Batal, Colloids Surf., B, 2019, 180, 411-428.

15 N. A. Dhas, C. P. Raj and A. Gedanken, Chem. Mater., 1998, 10, 1446-1452.

16 G. S. El-Sayyad, F. M. Mosallam and A. I. El-Batal, $A d v$. Powder Technol., 2018, 29, 2616-2625.

17 K. Kanagamani, P. Muthukrishnan, K. Shankar, A. Kathiresan, H. Barabadi and M. Saravanan, J. Cluster Sci., 2019, 30, 1415-1424.

18 Y. M. Amin, A. M. Hawas, A. El-Batal and S. H. H. E. Elsayed, Br. J. Pharmacol. Toxicol., 2015, 6, 22-38.

19 K. L. Aillon, Y. Xie, N. El-Gendy, C. J. Berkland and M. L. Forrest, Adv. Drug Delivery Rev., 2009, 61, 457-466.

20 M. Khairy, R. O. Kadara, D. K. Kampouris and C. E. Banks, Anal. Methods, 2010, 2, 645-649.

21 M. Chauhan, T. Jasrotia, G. Kaur, C. Prakash, R. Kumar, N. Dilbaghi, G. R. Chaudhary and S. Kumar, Environ. Res., 2020, 180, 108857.

22 R. Hernandez-Delgadillo, D. Velasco-Arias, J. J. MartinezSanmiguel, D. Diaz, I. Zumeta-Dube, K. Arevalo-Niño and C. Cabral-Romero, Int. J. Nanomed., 2013, 8, 1645.

23 A. I. El-Batal, G. S. El-Sayyad, A. El-Ghamry, K. M. Agaypi, M. A. Elsayed and M. Gobara, J. Photochem. Photobiol., B, 2017, 173, 120-139.

24 S. Badger, S. Abraham, H. Stryhn, D. J. Trott, D. Jordan and C. G. Caraguel, Prev. Vet. Med., 2019, 172, 104782.

25 M. Balouiri, M. Sadiki and S. K. Ibnsouda, J. Pharmaceut. Biomed. Anal., 2016, 6, 71-79.

26 F. M. Mosallam, G. S. El-Sayyad, R. M. Fathy and A. I. ElBatal, Microb. Pathog., 2018, 122, 108-116.

27 G. D. Christensen, W. A. Simpson, A. L. Bisno and E. H. Beachey, Infect. Immun., 1982, 37, 318-326.

28 M. A. Ansari, H. M. Khan, A. A. Khan, S. S. Cameotra and R. Pal, Appl. Nanosci., 2014, 4, 859-868.

29 G. S. El-Sayyad, M. A. Elkodous, A. M. El-Khawaga, M. A. Elsayed, A. I. El-Batal and M. Gobara, RSC Adv., 2020, 10, 5241-5259.

30 M. A. Maksoud, G. S. El-Sayyad, A. Ashour, A. I. El-Batal, M. A. Elsayed, M. Gobara, A. M. El-Khawaga, E. AbdelKhalek and M. El-Okr, Microb. Pathog., 2019, 127, 144-158.

31 K. Brownlee, Probit Analysis: A Statistical Treatment of the Sigmoid Response Curve, J. Am. Stat. Assoc., 1952, 47, 687691.

32 M. Składanowski, M. Wypij, D. Laskowski, P. Golińska, H. Dahm and M. Rai, J. Cluster Sci., 2017, 28, 59-79.

33 P. Ramos, B. Pilawa, P. Pepliński, T. O. Sunmonu, F. B. Lewu, I. Koca, B. Tekguler, V. A. Yilmaz, S. Shoba and M. Sathiavelu, Indian J. Pharm. Educ. Res., 2019, 53, S186S192.

34 G. S. El-Sayyad, H. S. El-Bastawisy, M. Gobara and A. I. ElBatal, Biol. Trace Elem. Res., 2019, 1-20, DOI: 10.1007/ s12011-019-01842-z.

35 A. I. El-Batal, F. M. Mosallam, M. M. Ghorab, A. Hanora, M. Gobara, A. Baraka, M. A. Elsayed, K. Pal, R. M. Fathy, 
M. Abd Elkodous and G. S. El-Sayyad, Int. J. Biol. Macromol., 2019, DOI: 10.1016/j.ijbiomac.2019.11.210.

36 M. I. A. Abdel Maksoud, G. S. El-Sayyad, A. Abokhadra, L. I. Soliman, H. H. El-Bahnasawy and A. H. Ashour, J. Mater. Sci.: Mater. Electron., 2020, DOI: 10.1007/s10854-01902799-4.

37 A. Ashour, A. I. El-Batal, M. A. Maksoud, G. S. El-Sayyad, S. Labib, E. Abdeltwab and M. El-Okr, Particuology, 2018, 40, 141-151.

38 C. Jadhav, P. K. Pagare, K. Inamdar and L. Kadam, Macromol. Symp., 2019, 387, 1800198, DOI: 10.1002/masy.201800198.

39 M. G. Naseri, E. Saion and N. K. Zadeh, Int. Nano Lett., 2013, 3, 19.

40 D. Sánchez-Martínez, I. Juárez-Ramírez, L. M. TorresMartínez and I. de León-Abarte, Ceram. Int., 2016, 42, 2013-2020.

41 P. Belavi, G. Chavan, L. Naik, R. Somashekar and R. Kotnala, Mater. Chem. Phys., 2012, 132, 138-144.

42 M. A. Maksoud, G. S. El-Sayyad, A. Ashour, A. I. El-Batal, M. S. Abd-Elmonem, H. A. Hendawy, E. Abdel-Khalek, S. Labib, E. Abdeltwab and M. El-Okr, Mater. Sci. Eng., C, 2018, 92, 644-656.

43 M. Gondal, T. A. Saleh and Q. Drmosh, Sci. Adv. Mater., 2012, 4, 507-510.

44 S. H. Hussein-Al-Ali, M. E. El Zowalaty, A. U. Kura, B. Geilich, S. Fakurazi, T. J. Webster and M. Z. Hussein, BioMed Res. Int., 2014, 2014, 651831, DOI: 10.1155/2014/651831.

45 E. R. Arakelova, S. G. Grigoryan, F. G. Arsenyan, N. S. Babayan, R. M. Grigoryan and N. K. Sarkisyan, Int. J. Med. Heal. Pharm. Biomed. Eng., 2014, 8, 33-38.

46 Z.-X. Tang and B.-F. Lv, Braz. J. Chem. Eng., 2014, 31, 591601.
47 A. R. Badireddy, R. Hernandez-Delgadillo, R. I. SánchezNájera, S. Chellam and C. Cabral-Romero, J. Nanopart. Res., 2014, 16, 2456.

48 M. Shakibaie, E. Hajighasemi, M. Adeli-Sardou, M. Doostmohammadi and $\mathrm{H}$. Forootanfar, IET Nanobiotechnol., 2019, 13, 377-381.

49 P. Nazari, R. Dowlatabadi-Bazaz, M. Mofid, M. Pourmand, N. Daryani, M. Faramarzi, Z. Sepehrizadeh and A. Shahverdi, Appl. Biochem. Biotechnol., 2014, 172, 570-579. 50 C. Ashajyothi, K. H. Harish, N. Dubey and R. K. Chandrakanth, J. Nanostruct. Chem., 2016, 6, 329-341. 51 H.-J. Park, H. Y. Kim, S. Cha, C. H. Ahn, J. Roh, S. Park, S. Kim, K. Choi, J. Yi and Y. Kim, Chemosphere, 2013, 92, 524-528.

52 S. Priyadarshini, A. Mainal, F. Sonsudin, R. Yahya, A. A. Alyousef and A. Mohammed, Res. Chem. Intermed., 2019, 46, 1077-1089.

53 P. K. Stoimenov, R. L. Klinger, G. L. Marchin and K. J. Klabunde, Langmuir, 2002, 18, 6679-6686.

54 M. F. Khan, A. H. Ansari, M. Hameedullah, E. Ahmad, F. M. Husain, Q. Zia, U. Baig, M. R. Zaheer, M. M. Alam and A. M. Khan, Sci. Rep., 2016, 6, 27689.

55 W. Umbreit, J. Biol. Chem., 1949, 177, 703-714.

56 M. Abudayyak, E. Öztaș, M. Arici and G. Özhan, Chemosphere, 2017, 169, 117-123.

57 R. Liman, Chemosphere, 2013, 93, 269-273.

58 J. A. Kovrižnych, R. Sotníková, D. Zeljenková, E. Rollerová, E. Szabová and S. Wimmerová, Interdiscip. Toxicol., 2013, 6, 67-73.

59 M. Ahamed, R. Posgai, T. J. Gorey, M. Nielsen, S. M. Hussain and J. J. Rowe, Toxicol. Appl. Pharmacol., 2010, 242, 263-269.

60 Y. Luo, C. Wang, Y. Qiao, M. Hossain, L. Ma and M. Su, J. Mater. Sci.: Mater. Med., 2012, 23, 2563-2573. 